\title{
The Andean Biotic Index (ABI): revised tolerance to pollution values for macroinvertebrate families and index performance evaluation
}

\author{
Blanca Ríos-Touma ${ }^{1,2 *}$, Raúl Acosta \& Narcís Prat ${ }^{2}$ \\ 1. Freshwater Ecology and Management, Department of Ecology, University of Barcelona, Av. Diagonal 645, Barcelona. \\ 08028,Spain.racosta@ub.edu,nprat@ub.edu \\ 2. Centro de Investigación de la Biodiversidad y el Cambio Climático -BioCamb-, Universidad Tecnológica \\ Indoamérica, Av. Machala y Sabanilla , $4^{\text {to }}$ piso, Quito, Ecuador EC170103; briostouma@gmail.com \\ * Correspondence
}

Received 12-XII-2013. Corrected 20-I-2014. Accepted 13-II-2014.

\begin{abstract}
Score-based biotic indices are widely used to evaluate the water quality of streams and rivers. Few adaptations of these indices have been done for South America because there is a lack of knowledge on macroinvertebrate taxonomy, distribution and tolerance to pollution in the region. Several areas in the Andes are densely populated and there is need for methods to assess the impact of increasing human pressures on aquatic ecosystems. Considering the unique ecological and geographical features of the Andes, macroinvertebrate indices used in other regions must be adapted with caution. Here we present a review of the literature on macroinvertebrate distribution and tolerance to pollution in Andean areas above 2000 masl. Using these data, we propose an Andean Biotic Index (ABI), which is based on the BMWP index. In general, ABI includes fewer macroinvertebrate families than in other regions of the world where the BMWP index has been applied because altitude restricts the distribution of several families. Our review shows that in the high Andes, the tolerance of several macroinvertebrate families to pollution differs from those reported in other areas. We tested the ABI index in two basins in Ecuador and Peru, and compared it to other BMWP adaptations using the reference condition approach. The ABI index is extremely useful for detecting the general impairment of rivers but class quality boundaries should be defined independently for each basin because reference conditions may be different. The ABI is widely used in Ecuador and Peru, with high correlations with land-use pressures in several studies. The ABI index is an integral part of the new multimetric index designed for high Andean streams (IMEERA). Rev. Biol. Trop. 62 (Suppl. 2): 249-273. Epub 2014 April 01.
\end{abstract}

Key words: Andes, aquatic macroinvertebrates, altitudinal distribution, tolerance to pollution, BMWP adaptations, biomonitoring, water quality.

Aquatic macroinvertebrates are ubiquitous, and their sensitivity to environmental changes makes them good indicators of water condition. Diversity and biotic indices for benthic macroinvertebrate samples are often applied in an attempt to measure river pollution (Giller \& Malmqvis, 1998). Score-based biotic indices are one of the most common biomonitoring methods used by water managers to synthesize large amounts of data from environmental monitoring. In these indices, a score is given to taxa (usually family or genera level) according to tolerance to organic pollution, giving highest or lowest scores (depending on the index) to sensitive taxa. These indices synthesize ecological information and the results are more accessible to non-biologists who require data for management purposes (Armitage, Moss, Wright \& Furse; 1983). Indices of this kind were developed mainly in Europe (Woodiwiss, 1964; Armitage et al., 1983), South Africa (Chutter, 1972), North America (Hilsenhoff, 1982; 1987) and Australia (Chessman, 1995). One of the most commonly used index is the BMWP (and its derivations), which was developed in 1978 by the Biological Monitoring 
Working Party (BMWP) in the United Kingdom (Armitage et al., 1983). This index gives a score to each taxa (mostly families) according to the sensitivity of pollution (mainly organic), being the most sensitive taxa scored with values of 10 and the less sensitive (or more resistant) to pollution a score of 1 . It has been adapted to many countries, such as Poland (Czerniawska-Kusza, 2005), Canada (Barton \& Metcalfe-Smith, 1992), Thailand (Mustow, 2002) and Spain (Alba-Tercedor \& SanchezOrtega, 1988; Zamora-Muñoz \& Alba-Tercedor, 1996), and modified versions of this last one are currently used in other countries, such as Portugal (Chaves, Costa, Chainho, Costa \& Prat, 2006) and Greece (Skoulikidis, Gritzalis \& Kouvarda, 2002), as a monitoring tool. Currently, several European countries are considering this index to assess ecological status, as required by the European Water Framework Directive. For example, the IBMWP index has been extensively used as monitoring tool in Spain (e.g. GUADALMED project, www. ub.edu/fem, Alba-Tercedor et al., 2002).

In developing countries, interest in biological monitoring of water bodies has increased in recent years. In the Andean mountain ranges, a number of studies from Colombia, Ecuador, Bolivia, Argentina, Venezuela, and Chile have used macroinvertebrates as biological indicators (Roldán Builes, Trujillo \& Suárez, 1973; Zúñiga de Cardozo, Rojas de Hernández \& Mosquera, 1997; Domínguez \& Fernández, 1998; Posada, Roldán \& Ramírez, 2000; Pescador, Hubbard \& Zúñiga, 2001; Figueroa, Valdovinos, Araya \& Parra, 2003), and several of these studies applied modified versions of the BMWP index (Jacobsen, 1998; Roldán, 1999; Vásconez, 2000; Fernandez, Romero, Vece, Manzo, Nieto \& Orce, 2002; Riss, Ospina \& Gutierrez, 2002; Leiva, 2004). Colombia and Argentina made their own preliminary adaptations of the index, which with few modifications, has been used in other countries of South America (see review by Prat, Ríos-Touma, Acosta \& Rieradevall, 2009). Although, macroinvertebrate families in the neotropics generally receive similar scores of sensitivity to organic pollution relative to families in temperate zones (Jacobsen \& Encalada, 1998; Tomanova \& Tedesco, 2007), little is known about the autoecology of Andean taxa. Moreover, in Andean areas the altitudinal gradient is very important and likely influences macroinvertebrate presence and resistance to pollution. In addition, considerable differences in basins (e.g. altitudinal limitations, vegetation changes and their effects on in the different types of river input) have not been taken into account in the various adaptations of the BMWP index to Andean streams, or studies have been performed in small basins without reference sites (Gutierrez, Riss \& Ospina, 2004). Therefore, scores obtained with these preliminary adaptations may not properly reflect water quality. Many areas of the Andes are densely populated; as a result, there is an urgent need for methods to assess water quality in these regions in an effective and affordable way. In this regard, the BMWP index is useful because of its simplicity. However, the BMWP index must be adapted in order to take into consideration the appropriate pollution score of each macroinvertebrate family.

Here we present the Andean Biotic Index (ABI) as a method that properly uses the rationale of the BMWP for the evaluation of biological quality of Andean streams, with the main goal of creating an improved tool that uses family scores appropriate for the Andean region. We had two specific aims: First we propose appropriate score values for representative macroinvertebrate families of Northern and Central Andean streams above 2000 meters. For this, we reviewed the different adaptations of the BMWP index currently being used in Andean regions and also survey published and unpublished data (from "gray literature") on the sensitivity of macroinvertebrate taxa to pollution in the region. The second aim was to construct and test the performance of the ABI in evaluating high-altitude Andean streams. We applied the ABI index to streams in basins of Ecuador and Peru and compared results with other indices used on the area and to family diversity as well. Finally, we assessed 
its performance along a gradient of human impacts. The ABI is already in use as part of the CERA (Calidad Ecológica de Ríos Altoandinos, Ecological Quality of High-Andean rivers; Acosta, Ríos-Touma, Rieradevall \& Prat, 2009). However, this is the first time the index is described and tested.

\section{MATERIALS AND METHODS}

Study area: The Andean ranges extend along western South America, from south Venezuela to Argentina (Tierra de Fuego). Gansser (1973) divided the Andean range into three regions: northern Andes, from Venezuela to the Huancabamba depression (in Peru); central Andes, from Huancabamba to $46^{\circ} \mathrm{S}$ in Argentina, transversal at the latitude of the Golfo de Penas; and southern Andes to Tierra de Fuego (see also Corvalán, 1990; Gregory-Wodzicki, 2000; Lavenu, 2006). Our target area included the northern Andes from the Venezuelan Andes to the Altiplano in the central Andes (Fig. 1). Maximum geomorphological complexity of the northern Andes is reached in Colombia, where they are divided into three main ranges: the western, central and eastern Cordilleras, separated by the sedimentary basins of the Cauca and Magdalena rivers (Kattan, Franco, Rojas $\&$ Morales, 2004). In Ecuador, the Andes are divided into the eastern and western ranges. The latter divides the Pacific and Atlantic slopes (Ulloa \& Jorgensen, 2004). The southern limits of the Eastern Cordillera are in northern Peru, at the Huancabamba depression, in an area where the chain is bisected approximately at $6^{\circ} \mathrm{S}$. This area forms a barrier that divides biogeographically the Andes in two regions (Myers, 2000). In Peru, the Andes include three mountain ranges: the western, central and eastern ranges (ONERN, 1970). The Altiplano Subdomain extends from $15^{\circ} \mathrm{S}$ in Peru to $24^{\circ} \mathrm{S}$ in Bolivia and includes lake Titicaca (Allmendinger, Jordan, Kay \& Isacks, 1997; Gregory-Wodzicki, 2000). The Andean ranges have steep gradients on their Pacific slopes (Pringle, Scatena, Paaby-Hansen \& Nuñez-Ferrera, 2000), resulting in rivers that are relatively short compared to other zones of Latin America. The Andean region includes basins that lie in mountain ranges and in the endorheic interAndean basins. We focused our bibliographic review on macroinvertebrate assemblages on fluvial systems (study area) from 2000masl to the highlands (more than $4500 \mathrm{~m}$ or below the perpetual glaciers), extending from latitude $24^{\circ} \mathrm{S}$ (limit of the Altiplano Sub domain) to the northern section of the Andes (Fig. 1).

Revision of pollution tolerance for Andean macroinvertebrate families: We reviewed more than 500 documents, including scientific publications of indexed journals and Latin American scientific journals (locally indexed). In addition, we reviewed gray literature in the form of university theses (BS, MSc and $\mathrm{PhD}$ ), seminar communications, and technical reports available from international meetings, local agencies and the web, many of them available only at governmental offices. This literature included species descriptions, ecological studies, and reports on monitoring and environmental impact. To make the final selection of taxa for our adaptation of the BMWP index, we focused on studies that included macroinvertebrate taxa listed together with data on water quality from the Andean regions of Colombia, Ecuador, Peru and Bolivia (more than 70 studies). In few cases, we did not find information on pollution tolerance for some families. In these cases we used the original score and European adaptations for comparison purposes. We focused the bibliographic search to our target area, but for comparison we included data from adaptations of similar indices used in Chile that sometimes are applied in lower altitude Andean regions.

ABI construction and testing: We constructed the ABI index using the same rationale as the original BMWP index. A score was assigned to each family (according to the review of literature made previously) and the total sum is the ABI score. Dividing this value for the total number of taxa found at one site, the Andean Average Score per Taxon 


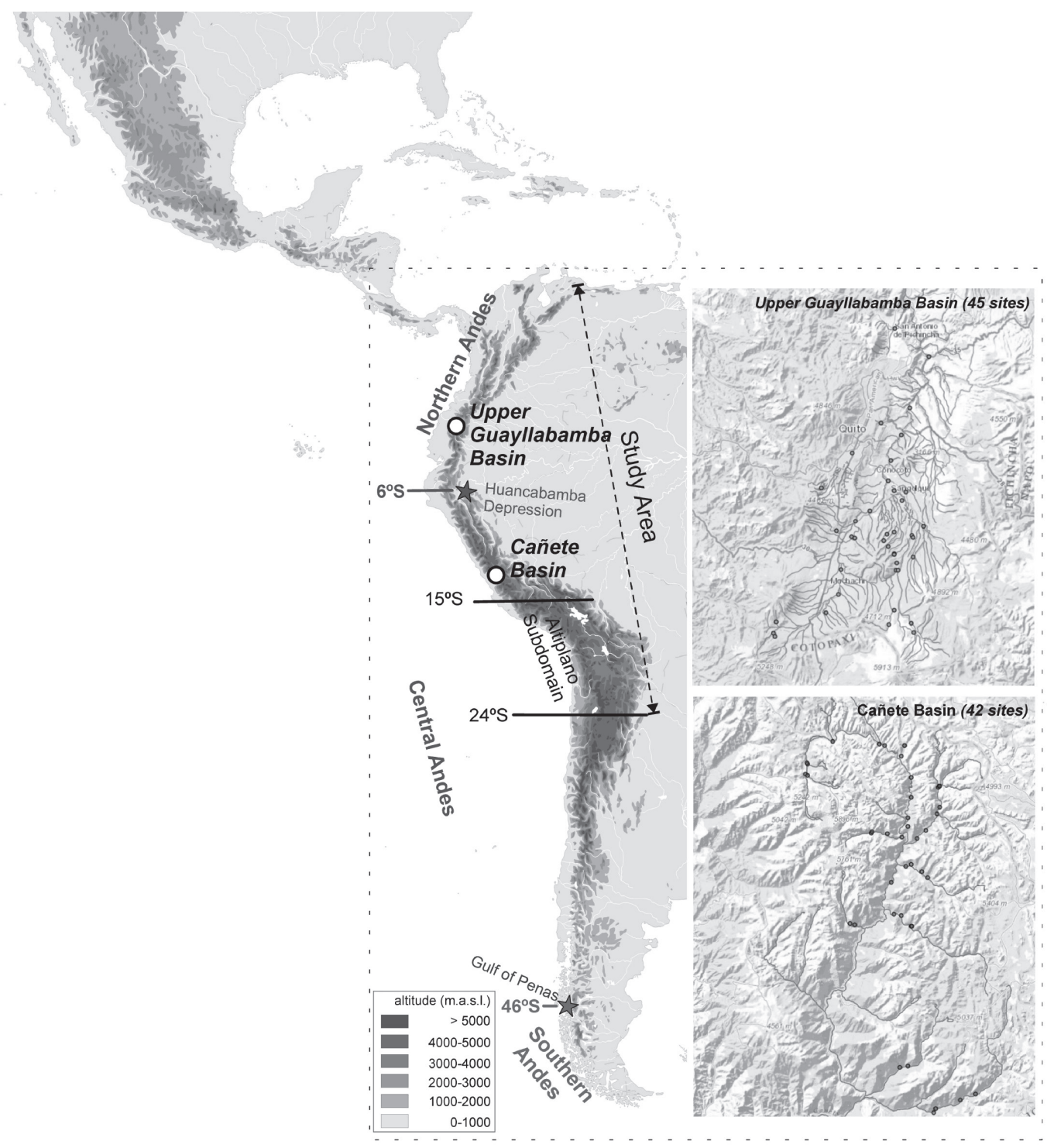

Fig. 1. Andean Mountain Range. Latitude $24^{\circ} \mathrm{S}$ marks the southern limit of our bibliographic research, and the north limit was at the end of the Andes in Venezuela. Latitude $6^{\circ} \mathrm{S}$ marks the area of the Huancabamba depression; $15^{\circ} \mathrm{S}$ marks the beginning of the Altiplano Sub domain (Map by Pau Fortuño, Universitat de Barcelona).

(AASPT) may be obtained. We used two basins to develop the index. These basins flow to the Pacific Ocean and are located in the Ecuadorian and Peruvian Andes. In Ecuador, we evaluated 45 sample sites located between 2200 to $3800 \mathrm{masl}$, in the upper Esmeraldas river basin, corresponding to the upper Guayllabamba river sub-basin. In Peru, we sampled 40 sites at the upper Cañete river basin, between 2500 to 4500masl. Sites were located at both Páramos (and Punas) and Andean forest. A detailed description of the basins and sampling sites of Peru can be found in Acosta et al. (2009).

We use the reference condition approach (Reynoldson, Norris, Resh, Day \& Rosenberg, 1997) to delimit the boundaries of quality 
classes. In this approach, the score "very good" is identified according to different criteria that enable us to discard sites that are altered by human activities as targets for water quality objectives. Given the limited information available on the region, we developed a simple method (adapted from Chaves et al., 2006) that allowed us to test whether a site is a potential reference. Evaluations were conducted using a fact-sheet that includes four groups of characteristics, assessing human impacts at: basin, hydrology, reach and site levels. This method is a summation that provides a reference index ranging from 0 to 120 , where values lower than 100 indicate that the site is not a good reference. This method and the validation of reference conditions in our study basins are described in Acosta et al. (2009). Applying the reference index to both basins, they found that $60 \%$ and $77 \%$ of the studied sites in Ecuador and Peru, respectively, could be considered as reference sites. We included all sites (reference and impaired) in our macroinvertebrate survey to validate $A B I$ index. However, several sites, especially in the Cañete Basin, were excluded due to mining sewage impacts, which have dramatic effects on the macroinvertebrate fauna. The ABI and BMWP are indices developed to assess the effects of organic pollution and riparian alteration, and cannot be used to evaluate mining effects on streams. As a consequence, data from the studied basins is skewed to the reference communities.

Macroinvertebrate sampling: We sampled the macroinvertebrate assemblages and environmental characteristics on summer of 2003 and 2004, collecting a total of 45 sample sites in Ecuador and 42 sampling sites in Peru. Following Guadalmed sampling method, we sampled the macroinvertebrate assemblage using a D-net (Alba-Tercedor et al., 2002, Bonada et al., 2002) in all habitats available (see also Acosta et al., 2009). Multihabitat sampling is required to apply this type of index (Alba-Tercedor \& Sanchez-Ortega, 1988). Samples were preserved in formaldehyde $10 \%$, transported to the laboratory, and examined under the stereoscope. Samples were sorted and macroinvertebrates identified to family level and counted to establish the relative abundance of taxa.

Definition of quality boundaries: Five quality classes were defined: excellent, good, moderate, poor and bad conditions, following the indications of the Water Framework Directive (WFD 2000). The threshold between classes for each index was defined for each basin (Ecuador or Peru) independently following a similar methodology of Barbour et al. (1996; 1999) and Alba-Tercedor et al. (2002). We used the 25 th percentile of the reference site values to define the boundary between excellent and good conditions. Following to the WFD (D.O.C.E., 2000; Alba-Tercedor et al., 2002) and considering that $\mathrm{ABI}$ is an adaptation of the BMWP, which has an exponential behavior in response to impact gradients (Munne \& Prat, 2009 ), class boundaries were defined at $61 \%$ (between moderate and good), 36\% (between moderate and poor), and $15 \%$ (between poor and bad) of the $25^{\text {th }}$ percentile of the index value at reference sites.

ABI relationship with environmental variables: In order to assess the performance of the ABI (validation of the proposed score values), we performed a Principal Components Analysis (PCA) using Primer 6 (United Kingdom). We included environmental parameters measured at each station (Appendix 1), including the index of riparian habitat (QBR-And), the physical habitat index (IHF) and the reference condition value (numerical value that resumes alteration at basin, hydrology, reach, and site) (see Acosta et al., 2009 for detailed description of all indices). Also the following water characteristics were included: nitrates (an indicator of eutrophication), conductivity, $\mathrm{pH}$, and dissolved oxygen. We chose the PCA component that explained most of the environmental variability and described environmental parameters closely related to this component (Appendix 1). Finally, we related this component to the $\mathrm{ABI}$ index to assess responses to 
environmental impairment. We used pooled data to maximize the number of impaired sites (that were fewest in the Cañete basin in Peru) and to have the widest range of conditions, and also for the Guayllabamba basin individually because it showed a wider set of conditions. We did not perform a separated analysis for Peru due to the low number of impacted sites.

\section{RESULTS}

Delimiting a high Andean fauna: In the analysis of published data, we found four versions of the BMWP currently in use in our target region: the original BMWP, the adaptation for the Iberian Peninsula (IBMWP), the adaptation for Antioquia, Colombia (BMWPA), and an adaptation for Chile (CHBWMP). These versions include up to 111 macroinvertebrate taxa, including some that do not occur in the neotropical region (e.g., Nemouridae) or occur only at low elevations (below 2000 masl). Therefore, a first step was to exclude taxa not reported for our target region (Table 1). We excluded $52 \%$ of the families in the original
BMWP, $44 \%$ of those in the IBMWP, $22 \%$ for the BMWPA, and $29 \%$ of the families in the CHBMWP.

Among non-insect taxa, we considered Turbellaria at class level, as Jacobsen \& Encalada (1998) did, because although Planariidae and Dugesiidae were reported in South America, most studies in the area only provide the presence of the class. Also, other identifications are erroneous, mixing Dugesiidae genera inside the Planariidae family (Roldán, 1996). Similarly, the Hirudinea class was taken as a whole because of a lack of taxonomic information, although in the literature Glossiphoniidae was the most reported family. Mollusca included 13 freshwater families (Alvarenga \& Ricci, 1981; Paraense, 1981) in South America. Of those Sphaeriidae, Planorbidae, Lymnaeidae, Physidae, Hydrobiidae and Ancylidae are the only families that have been reported in Andean areas above 2000masl (Posada et al., 2000; Carrera \& Gunkel, 2003; Jacobsen, 2004) and were the only ones included in our index. Benthic Crustacea reported in Andean areas includes: Ostracoda and Hyalellidae

TABLE 1

Number of aquatic macroinvertebrate families present in South America vs. families present in High Andean region

\begin{tabular}{lccl}
\multicolumn{1}{c}{$\begin{array}{c}\text { Order or } \\
\text { taxonomic group }\end{array}$} & $\begin{array}{c}\text { Number of families } \\
\text { in South America }\end{array}$ & $\begin{array}{c}\text { Number of families } \\
\text { in High Andes } \\
(2000 \mathrm{~m} \text { asl })\end{array}$ & \multicolumn{1}{l}{ Reference } \\
Turbellaria & $10^{\mathrm{a}}(?)$ & $?$ & \\
Hirudinea & 7 & 7 & Ringuelet, 1981 \\
Oligochaeta & 9 & $?$ & Gavrilov, 1981; Marchese, 2009 \\
Mollusca Gastropoda & 13 & $? 6^{\mathrm{b}}$ & Paraense, 1981; Cuezzo, 2009 \\
Mollusca Bivalvia & 4 & $?$ & Alvarenga \& Ricci 1981; Ituarte, 2009 \\
Amphipoda & 5 & 1 & Peralta, 2001; Peralta \& Grosso, 2009. \\
Hydracarina (Acari) & 22 & $?$ & Rosso de Ferradás \& Fernandez, 2001; 2009 \\
Ephemeroptera & 14 & 4 & Dominguez et al., 2011; 2009 \\
Odonata & 17 & 6 & Paulson, 2012; von Ellenrieder \& R. Garrison, 2009 \\
Plecoptera & 6 & 2 & Romero, 2001; Froehlich, 2009 \\
Heteroptera & 16 & 6 & Alvárez \& Roldán, 1983; Jacobsen, 2004; Mazzucconi et al., 2009 \\
Trichoptera & 21 & 13 & Angrisano \& Korob, 2001; Angrisano \& Sganga, 2009 \\
Lepidoptera & 8 & 1 & Romero \& Navarro, 2009 \\
Coleoptera & 29 & 11 & Archangelsky et al., 2009 \\
Diptera & 26 & 17 & Lizarralde de Grosso, 2001; 2009 \\
\hline
\end{tabular}

a Including interstitial microturberllarians.

b According to the information compiled in the present document. 
(Amphipoda) (Vásconez, 2000; Ríos-Touma, 2004; Ríos-Touma \& Prat, 2004; Acosta \& Prat, 2011). Hyalella is the only freshwater Hyalellidae genera present in South America (Peralta, 2001), but we kept this taxon as a family for the index. Although Acari includes 22 benthonic freshwater families reported for the continent (Rosso de Ferradás \& Fernandez, 2001; 2009), the Hydracarina group was taken as a whole, as in the IBMWP index system (Alba-Tercedor \& Sánchez-Ortega, 1988), because usually ecological studies do not include identifications for families or genera and therefore the environmental tolerance would be difficult to define.

With respect to insects, for Ephemeroptera we first excluded the families not found in Peru, Ecuador and Colombia using the checklist in Dominguez, Hubbard, Pescador, Molinari \& Nieto (2011). Of the families recorded, we excluded: Caenidae, Euthyplociidae and Polymitarcidae because they are limited to elevations below 2000masl, being more frequent in the Amazonian and Andean foot hills (Jacobsen, 2003; Monaghan et al., 2004; Jacobsen, 2004). The Odonata reported in South America (Paulson, 2012) includes 18 families, 14 in the tropical Andean regions, mainly in the Amazon and foothill region of the mountain range. Only the families Coenagrionidae, Calopterygidae, Polythoridae, Aeshnidae, Gomphidae and Libellulidae have been reported in the Andes (Roback, 1980b; Monaghan et al., 2000; Posada et al., 2000; Jacobsen, 2003; Jacobsen, 2004). Of the six families of Plecoptera in South America (Romero, 2001; Froehlich, 2009), only two (Perlidae and Gripopterygidae) occur in tropical Andean region (Illies, 1964; Roback, 1980a; Jacobsen, 2003; Jacobsen, 2004). Like Figueroa (2004), we included these two families in our adaptation of the BMWP index. In the case of Heteroptera, only five of the 13 families reported in Colombia (Álvarez \& Roldan, 1983) occur above 2000masl in the Andean tropical region: Veliidae, Gerridae, Corixidae, Notonectidae and Naucoridae (Posada et al., 2000; Carrera \& Gunkel, 2003; Jacobsen 2003; 2004).

Twenty one families of Trichoptera have been reported in South America (Angrisano
\& Korob, 2001; Angrisano \& Sganga, 2009) and we included thirteen of these in our index. These families were also used by Roldán (1999) in BMWPA index, but we also considered two families frequent in Andean highland streams but not included by other authors: Limnephilidae and Anomalopsychidae (Flint, 1982; Holzenthal \& Flint, 1995; Jacobsen, 2003; Jacobsen, 2004). In relation to Figueroa's index (2004), we excluded four families (Kokriidae, Phylorheytidae, Tasimiidae and Stenopsychidae) that are exclusive to the austral region of the continent, and two families (Ecnomidae and Sericostomatidae) that are widespread, but have not been reported in the high Andes. On the other hand, we include the only truly aquatic Lepidoptera family, Crambidae (as Pyralidae) (Romero, 2001; Romero \& Navarro, 2009). Of the 29 aquatic Coleoptera families in South America (Archangelsky, Manzo, Michat \& Torres, 2009), 11 are reported in our target area (Spangler, 1980; Machado \& Rincón, 1996; Jacobsen, 2003; Jacobsen, 2004). Of these, we excluded Limnichidae and Luthrochidae because there is a lack of information on distribution and tolerance to pollution.

The dipterans of South America include 26 families (Lizarralde de Grosso, 2001; 2009), 17 of which have been included in indices. Of these families, we excluded Rhagionidae, as it has not been reported in Andean highlands. Although Limoniidae are not distinguished from Tipulidae in some publications on the neotropics (Roback \& Coffman, 1983; Jacobsen, 2003; Jacobsen, 2004), we differentiated these two groups because they are separate families (Zoological Records; Tachet, 2000) and recent published information of pollution tolerance have been provided for these taxa as separate families (Rios- Touma, 2004; Villamarín, 2012).

Tolerance to pollution: In general, we maintained scores that did not change among the different BMWP indices available and also those that were supported by autecological information from Andean areas (Table 2). Families in Turbellaria, Hirudinea, Oligochaeta, and 
TABLE 2

Comparative table of BMWP and the different adaptations vs. the proposed index ABI (Andean Biotic Index)

\begin{tabular}{|c|c|c|c|c|c|c|c|}
\hline Order & Family & BMWP $^{1}$ & IBMWP $^{2}$ & $\mathrm{BMWPA}^{3}$ & CHBMWP $^{4}$ & $\mathrm{ABI}$ & $\begin{array}{l}\text { Bibliographic references } \\
\text { of pollution tolerance }\end{array}$ \\
\hline Turbellaria & & 5 & 5 & & 5 & 5 & Jacobsen, 1998; Vásconez, 2000; Ríos \& Prat, 2004 \\
\hline Hirudinea & & 3 & 3 & 3 & 3 & 3 & \\
\hline Oligochaeta & & 1 & 1 & 1 & 1 & 1 & \\
\hline \multirow[t]{5}{*}{ Gasteropoda } & Ancylidae & 6 & 6 & 6 & 6 & 6 & \\
\hline & Physidae & 3 & 3 & 3 & 3 & 3 & \\
\hline & Hydrobiidae & 3 & 3 & & & 3 & \\
\hline & Limnaeidae & 3 & 3 & 3 & 3 & 3 & \\
\hline & Planorbidae & 3 & 3 & 3 & 3 & 3 & \\
\hline Bivalvia & Sphaeriidae & 3 & 3 & & 3 & 3 & \\
\hline Amphipoda & Hyalellidae & & & 8 & 6 & 6 & $\begin{array}{l}\text { Viña-Vizcaíno \& Ramírez-Gonzáles, 1997; Jacobsen,1998; Ríos } \\
\text { \& Prat, } 2004\end{array}$ \\
\hline Ostracoda & & & 3 & & & 3 & Ríos-Touma \& Prat, 2004 \\
\hline Hydracarina & & & 4 & & 4 & 4 & \\
\hline \multirow[t]{4}{*}{ Ephemeroptera } & Baetidae & 4 & 4 & 8 & 4 & 4 & $\begin{array}{l}\text { Roldán, 1980; Jacobsen, 1998; Viña-Vizcaíno \& Ramírez- } \\
\text { Gonzáles, 1997; Zúñiga de Cardoso et al., 1997; Ríos \& Prat, } 2004\end{array}$ \\
\hline & Leptophlebiidae & 10 & 10 & 10 & 10 & 10 & \\
\hline & Leptohyphidae & & & 7 & & 7 & Roldán, 1980, 1992; Zúñiga de Cardoso et al.,1997 \\
\hline & Oligoneuridae & & 5 & 10 & 10 & 10 & Roldán, 1980; Zúñiga de Cardoso et al., 1997 \\
\hline \multirow[t]{6}{*}{ Odonata } & Aeshnidae & 8 & 8 & 6 & 8 & 6 & Arango \& Roldán, 1983 \\
\hline & Gomphidae & 8 & 8 & 10 & 8 & 8 & \\
\hline & Libellulidae & 8 & 8 & 6 & 8 & 6 & Arango \& Roldán, 1983 \\
\hline & Coenagrionidae & 6 & 6 & 6 & 6 & 6 & \\
\hline & Calopterygidae & 8 & 8 & 7 & 8 & 8 & \\
\hline & Polythoridae & & & 10 & & 10 & \\
\hline \multirow[t]{2}{*}{ Plecoptera } & Perlidae & 10 & 10 & 10 & 10 & 10 & \\
\hline & Gripopterygidae & & & & 10 & 10 & Turcotte \& Harper, 1982; Jacobsen, 1998; Vásconez, 2000 \\
\hline \multirow[t]{6}{*}{ Heteroptera } & Veliidae & & 3 & & & 5 & Alvarez \& Roldán, 1983 \\
\hline & Gerridae & & 5 & 3 & & 5 & Alvarez \& Roldán, 1983 \\
\hline & Corixidae & 5 & 3 & 7 & 3 & 5 & Alvarez \& Roldán, 1983 \\
\hline & Notonectidae & 5 & 3 & 5 & 3 & 5 & Alvarez \& Roldán, 1983 \\
\hline & Belostomatidae & & & 4 & 4 & 4 & \\
\hline & Naucoridae & 5 & 3 & 4 & & 5 & \\
\hline \multirow[t]{13}{*}{ Trichoptera } & Helicopsychidae & & & 10 & & 10 & Ballesteros et al., 1997; Jacobsen, 1998 \\
\hline & Calamoceratidae & & 10 & 10 & 10 & 10 & \\
\hline & Odontoceridae & 10 & 10 & 10 & & 10 & \\
\hline & Leptoceridae & 10 & 10 & 8 & 10 & 8 & $\begin{array}{l}\text { Ballesteros et al., 1997; Viña-Vizcaíno \& Ramírez-Gonzáles, 1997; } \\
\text { Jacobsen, } 1998\end{array}$ \\
\hline & Polycentropodidae & 7 & 10 & 8 & 7 & 8 & Correa et al., 1981; Ballesteros et al., 1997 \\
\hline & Hydroptilidae & 6 & 6 & 8 & 6 & 6 & Flint, 1991 \\
\hline & Xiphocentronidae & & & 8 & & 8 & Roldán et al., 1992 \\
\hline & Hydrobiosidae & & & 8 & 7 & 8 & Ballesteros et al., 1997; Jacobsen, 1998 \\
\hline & Glossosomatidae & & 8 & 7 & 8 & 7 & Viña-Vizcaíno \& Ramírez-Gonzáles, 1997; Jacobsen, 1998 \\
\hline & Hydropsychidae & 5 & 5 & 5 & 5 & 5 & \\
\hline & Anomalopsychidae & & & & 10 & 10 & Jacobsen ,1998; Holzenthal \& Flint, 1995 \\
\hline & Philopotamidae & 8 & 8 & 8 & & 8 & Flint, 1991 \\
\hline & Limnephilidae & 7 & 7 & & 7 & 7 & Flint, 1982 \\
\hline Lepidoptera & Pyralidae & & 4 & 4 & & 4 & \\
\hline
\end{tabular}


TABLE 2 (Continued)

\begin{tabular}{|c|c|c|c|c|c|c|c|}
\hline Order & Family & BMWP1 & IBMWP $^{2}$ & $\mathrm{BMWPA}^{3}$ & CHBMWP $^{4}$ & $\mathrm{ABI}$ & $\begin{array}{l}\text { Bibliographic references } \\
\text { of pollution tolerance }\end{array}$ \\
\hline \multirow[t]{11}{*}{ Coleoptera } & Ptilodactylidae & & & 10 & & 5 & Viña-Vizcaíno \& Ramírez-Gonzáles, 1997 \\
\hline & Lampyridae & & & 10 & & 5 & \\
\hline & Psephenidae & & & 10 & 4 & 5 & \\
\hline & $\begin{array}{l}\text { Scirtidae } \\
\text { (Helodidae) }\end{array}$ & 5 & 3 & 7 & & 5 & \\
\hline & Staphylinidae & & & 6 & & 3 & \\
\hline & Elmidae & 5 & 5 & 6 & 5 & 5 & \\
\hline & Dryopidae & 5 & 5 & 6 & 5 & 5 & \\
\hline & Gyrinidae & 5 & 3 & 3 & 3 & 3 & \\
\hline & Dytiscidae & 5 & 3 & & 3 & 3 & \\
\hline & Hydrophilidae & 3 & 3 & 3 & 3 & 3 & \\
\hline & Hydraenidae & & 5 & & & 5 & \\
\hline \multirow[t]{17}{*}{ Diptera } & Blepharoceridae & & 10 & 10 & 10 & 10 & \\
\hline & Simuliidae & 5 & 5 & 8 & 5 & 5 & $\begin{array}{l}\text { Viña-Vizcaíno \& Ramírez-Gonzáles, 1997; Jacobsen, 1998; Ríos } \\
\text { \& Prat, } 2004\end{array}$ \\
\hline & Tabanidae & 5 & 4 & 4 & 4 & 4 & \\
\hline & Tipulidae & & 5 & 4 & 5 & 5 & \\
\hline & Limoniidae & 4 & 4 & & 4 & 4 & \\
\hline & Ceratopogonidae & & 4 & 4 & 4 & 4 & \\
\hline & Dixidae & & 4 & & 4 & 4 & \\
\hline & Psychodidae & & 4 & 4 & 4 & 3 & $\begin{array}{l}\text { Machado et al., 1997; Jacobsen, 1998; Vásconez, 2000; Ríos \& } \\
\text { Prat, } 2004\end{array}$ \\
\hline & Dolichopodidae & & 4 & 4 & & 4 & \\
\hline & Stratiomyidae & & 4 & 4 & 4 & 4 & \\
\hline & Empididae & & 4 & 4 & 4 & 4 & \\
\hline & Chironomidae & 2 & 2 & 2 & 2 & 2 & \\
\hline & Culicidae & & 2 & 2 & 2 & 2 & \\
\hline & Muscidae & & 4 & 2 & & 2 & Jacobsen, 1998 \\
\hline & Ephydridae & & 2 & & 2 & 2 & \\
\hline & Athericidae & & 10 & & 10 & 10 & \\
\hline & Syrphidae & & 1 & & 1 & 1 & \\
\hline
\end{tabular}

1. (England) (Armitage et al., 1983).

2. (Iberian Peninsula) (Alba-Tercedor \& Sánchez-Ortega, 1988).

3. (Antioquia, Colombia) (Roldán, 1999).

4. (Chile) (Figueroa, 2004).

Mollusca were assigned the same scores they received in available adaptations of the BMWP index. Moreover, these values are consistent with the presence of these taxa in a wide range of water conditions (Machado et al., 1997; Viña-Vizcaíno \& Ramírez-Gonzáles, 1997; Jacobsen \& Encalada, 1998; Vásconez, 2000; Ríos-Touma, 2004; Ríos-Touma \& Prat, 2004).

Hyalellidae is found in a wide variety of habitats, shows diverse feeding strategies (Peralta, 2001; Acosta \& Prat, 2011), and is resistant to certain types of organic pollution (Jacobsen \& Encalada, 1998). Therefore, we used the score for Gammaridae (6) from the index developed by Armitage et al. (1983), which is consistent with the frequent presence of this family in reference to mildly impaired streams. For Ostracoda (3) and Hydracarina (4) we also used the original IBMWP index value, because the pattern found in the literature was consistent with the presence of these taxa in more impaired streams. 
Within Ephemeroptera, Leptophlebiidae was given the same score (10) as in all the indices analyzed, because we did not find this family under impaired conditions. For Leptohyphidae, we used the score (7) reported by Roldán (1999), as the family is present in slightly polluted waters (e.g. Roldán, 1980; Roldán, 1996; Zúniga de Cardoso et al., 1997; Viña-Vizcaíno \& Ramírez-Gonzáles, 1997). In contrast, to some studies, we maintained Oligoneuriidae with a high score (10) because this family is reported only in clean waters (e.g. Roldán, 1996; Zúniga de Cardoso, 1997; Rios-Touma, 2004). Although Roldan (1999) assigned a score of 8 to Baetidae, we used a value of, 4 as in the original BMWP index, as this family is commonly found in polluted waters (e.g. Roldán, 1980; Viña-Vizcaíno \& Ramírez-Gonzáles, 1997; Zúñiga de Cardoso et al., 1997; Jacobsen \& Encalada, 1998; Ríos \& Prat, 2004).

Information found on Gomphidae (8), Coenagrionidae (6) and Calopterygidae (8) was consisted with the original scores assigned by Armitage et al. (1983). For Aeshnidae and Libellulidae we used the scores given by Roldán (1999) because these groups show a higher tolerance to pollution in Andean streams (Álvarez \& Roldán, 1983). The BMWPA adaptation was the only index to include the Polythoridae family and this was the only Odonata family to achieve a maximal score. In our adaptation, we kept this score for this family as larvae is found in clean mountain rivers (Bick \& Bick, 1985; Acosta, 2003; Sanchez-Herrera \& Realpe, 2010).

For Plecoptera, we maintained the maximal score reported, because these families are found only in clean sites above $2000 \mathrm{~m}$ asl (Ríos-Touma, 2004; Acosta, 2005; Acosta et al., 2009). For most Heteroptera families we used a score of 5, as they show similar resistance to moderately polluted waters (Álvarez \& Roldán, 1983). For Naucoridae, Notonectidae, and Corixidae the score (5) used was that same as that reported in Armitage et al. (1983), because with the ability of live in moderately impaired streams mainly due to their semi-aquatic life. For the Belostomatidae we applied a score of 4, given by Roldán (1999) and Figueroa (2004) for its better resistance to pollution than other heteropterans.

Regarding Trichoptera, in our adaptation, Calamoceratidae and Odontoceridae were kept at the highest value. Hydroptilidae (6), Hydropsychidae (5), Philopotamidae (8), and Limnephilidae (7) maintained the scores reported in the original BMWP index. We also used the scores reported by Roldán (1999) for Helicopsychidae, Leptoceridae, Polycentropodidae, Xiphocentronidae, Hydrobiosidae and Glossosomatidae, because of their concordance with the literature (e.g., Correa, Machado \& Roldán, 1981; Flint, 1991; Ballesteros, Zúñiga de Cardoso \& Rojas de Hernández, 1997; ViñaVizcaíno \& Ramírez-Gonzáles, 1997; Jacobsen \& Encalada, 1998). On the other hand, Anamolopsychidae maintained the maximum score assigned by Figueroa (2004), which is also consistent with data reported by Jacobsen \& Encalada (1998), Holzenthal \& Flint (1995) and Holzenthal \& Ríos-Touma (2012). For the Lepidoptera, Crambidae, we maintained the scores assigned in the IBMWP index and in the Antioquia index, although there is a lack of information on the resistance of this family to pollution.

There is little data on water pollution tolerance for Coleoptera in South America, and most data is associated with species descriptions (e.g., Gustafson \& Short, 2010; Perkins, 2011). Ptilodactylidae, Lampyridae, Hydraenidae, and Psephenidae are abundant in the Andes and absent from European indices. Therefore, they were assigned a score of 5, which is the maximum value for Coleoptera families that are usually semi-aquatic and have respiratory adaptations that make them less vulnerable to water quality. Elmidae, Dryopidae, and Hydrophilidae maintained the same values as in the indices analyzed due to the dominance of semi-aquatic life cycles (e.g., Hansen, 1991). Staphylinidae was scored 3, because this family shows adaptations that make it less responsive to water quality (Merrit \& Cummins, 1996). The same applies to 
Dytiscidae and Gyrinidae, which maintained the scores reported in the other BMWP adaptations for South America. This is also supported by information on the presence under strong organic pollution and their role as decomposers of animal tissues in Andean streams (Barrios \& Wolf, 2011).

Most adaptations of the BMWP index to South America have similar scores for dipteran families. Given the limited information available, we mostly used the same scores. We changed scores for two families reported by Roldán (1999), because they were not consistent with the information on Andean polluted waters (Machado et al., 1997; Viña-Vizcaíno \& Ramírez-Gonzáles, 1997; Jacobsen \& Encalada, 1998; Ríos \& Prat, 2004). Simuliidae, and particularly Psychodidae, had lower scores in our adaptation because they may be present on low water quality streams, especially the latter, which was present under highly toxic concentrations of pollutants in Andean rivers (Machado et al., 1997; Vásconez, 2000; Jacobsen \& Encalada, 1998; Ríos- Touma, 2004).

\section{Application of the ABI to Andean riv-} ers: The threshold between quality classes defined for each basin through the quartile method (Table 3), showed higher minimum and maximum values for $\mathrm{ABI}$ in all reference sites, which allowed easier differentiation of the excellent and good quality classes compared to BWMPA and CHBMWP. ABI was the index that arrived to the highest scores for reference sites, meaning more information (families) included.

We found a naturally lower family richness in reference sites of Cañete basin compared to the Guayllabamba basin. The limit between excellent and good classes in Guayllabamba basin was 96; in the Cañete basin it was 74 . The final quality values for all sites and all metrics and indices were highly correlated (Spearman correlation $\mathrm{p}<0.05$ ), showing that all indices were providing similar information, but these similarities were caused by the extreme classes (excellent or bad) with important differences in intermediate quality classes (Table 3). Also,

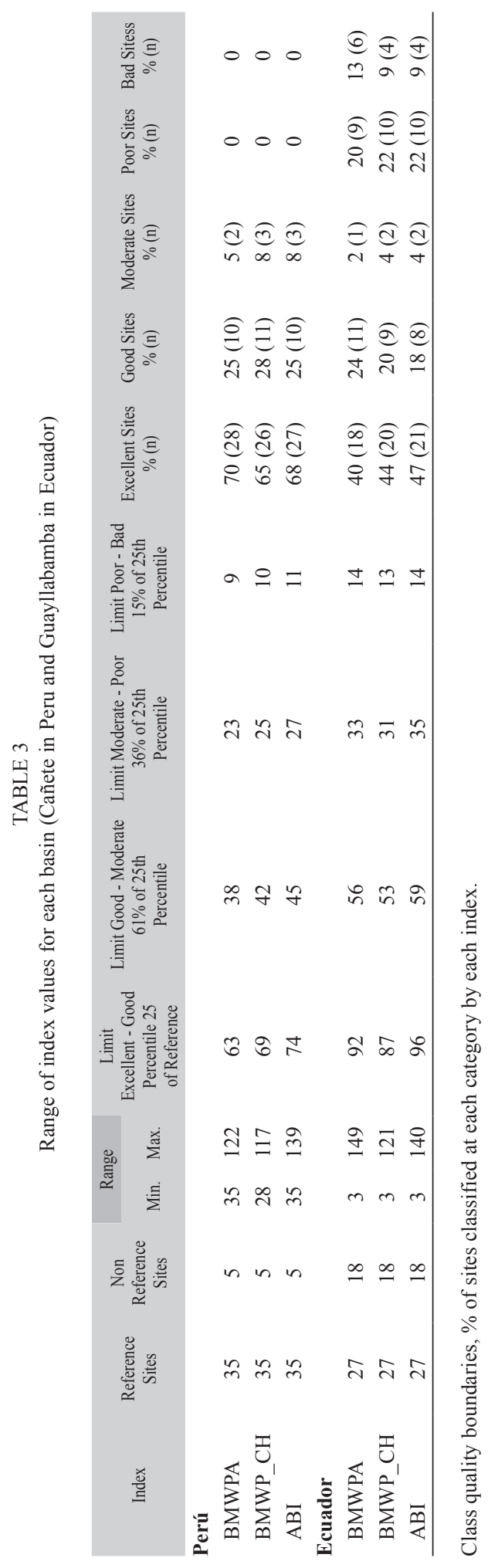


the Guayllamamba basin had more sites with moderate to bad quality classes (35\% of sites), which made the differences clearer between quality classes than at the Cañete basin that did not had sites with poor and bad quality classes.

For the pooled data, the first component of the PCA explained $61.4 \%$ of the environmental variation. The main contributions were a positive relation of conductivity with the first component and a negative correlation with the QBR index in the second component (Table 4). Also, we found a positive relation of the $2^{\text {nd }}$ component with nitrates and temperature and a negative relation with the reference score. These components had a highly significant inverse Pearson correlation $(\mathrm{r}=-0.53,-0.45$, respectively $\mathrm{p}<0.001)$ with the $A B I$, indicating that higher $\mathrm{ABI}$ scores were found at sites with better riparian and chemical quality at the site. The same analysis only for Ecuadorian sites (than included a wider set of impairment conditions than Peru) showed even a stronger correlation with the first component of PCA, that for this basin explained up to $69 \%$ of the environmental variation (Fig. 2). The second component also showed a strong positive relation with nitrates, showing a possible effect of eutrophication at lower ABI values. Although IHF was not strongly represented in any of the two PCA components, at Guayabamba sites it has a positive relationship with ABI (Pearson correlation $=0.7$ ).

\section{DISCUSSION}

Here we reviewed most of the information available for benthic freshwater macroinvertebrates in Andean areas, with emphasis on their resistance to pollution, in order to propose an adaptation of the BMWP index for the Andes. Although there have been recent important advances in the taxonomy of South American aquatic invertebrates (e.g., Fernandez \& Dominguez, 2001; Dominguez \& Fernandez, 2009) and for some Latin American countries (e.g., Hanson, Springer \& Ramírez, 2010), most information is still limited to unpublished "gray literature" (Pringle, 2000; Pringle et al., 2000) and studies that classify macroinvertebrates to family level only. A considerable part of the information included in the present work is focused on the analysis of technical reports, conference summaries, and local scientific publications. We also examined taxonomical descriptions from journals of restricted distribution, often not available in developing countries.

TABLE 4

Scores for the first and second PCA components for environmental parameters in the upper Guayllabamba basin (Ecuador) and pooled data from Ecuador and Peru

\begin{tabular}{lcccc}
\multicolumn{1}{c}{ Variables } & \multicolumn{2}{c}{ Pooled data } & Ecuador \\
Oxygen & PCA 1 & PCA 2 & PCA 1 & PCA 2 \\
Conductivity & -0.064 & -0.135 & -0.088 & 0.016 \\
pH & $\mathbf{0 . 9 5 5}$ & -0.27 & $\mathbf{0 . 8 7 8}$ & $\mathbf{- 0 . 4 5 4}$ \\
Nitrates & 0.041 & -0.035 & 0.027 & -0.031 \\
Temperature & 0.139 & $\mathbf{0 . 5 1}$ & 0.284 & $\mathbf{0 . 6 4 8}$ \\
Reference Score & 0.139 & $\mathbf{0 . 3 3 1}$ & 0.156 & 0.087 \\
IHF & -0.099 & -0.26 & -0.163 & $\mathbf{- 0 . 3 3 8}$ \\
QBR & -0.1 & -0.007 & -0.138 & -0.191 \\
\% Cumulative Variation explained & -0.156 & $-\mathbf{0 . 6 8 6}$ & -0.264 & $\mathbf{- 0 . 4 6 3}$ \\
Eigenvalue & 61.4 & 76.9 & 69.6 & 79.5 \\
Correlation with ABI & 0.693 & 0.175 & 0.883 & 0.126 \\
\hline
\end{tabular}

Eigenvalues, $\%$ of variation and correlation with $\mathrm{ABI}$ provided. 


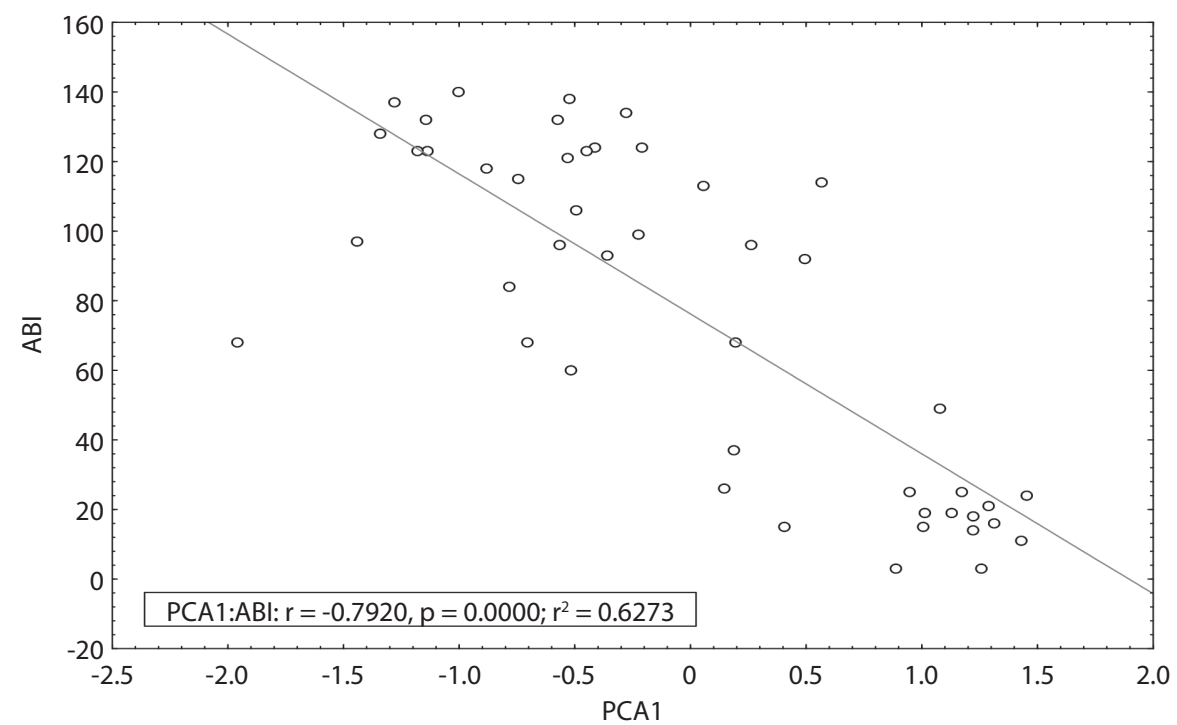

Fig. 2. Correlation between PCA 1 and Andean Biotic Index (ABI) in the upper Guayllabamba River Basin, Ecuador. PCA 1 had significant negative relationships with reference score, Andean Biotic Index, Habitat Index and positive with Conductivity and Nitrates.

Although the distribution of several families in the study area is still incomplete, we obtained enough information to make a selection of taxa commonly found in the high Andes, which is appropriate for a biotic index (Table 1). Ecuador was the only country well studied, as Jacobsen, Schultz \& Encalada (1997) and Jacobsen $(2003$; 2004) performed a thorough revision of the distribution of macroinvertebrate families. Our review is now adding information on macroinvertebrate families present in the Andean regions of Colombia (Arango \& Roldán, 1983; Álvarez \& Roldán, 1983; Zúñiga de Cardoso et al., 1997; Posada et al., 2000) Peru (Roback et al., 1980, Roback \& Coffman, 1983; Acosta, 2001; 2005) and Bolivia (Illies, 1964; 1967; Roback et al., 1980; Roback \& Coffman, 1983; Rocabado \& Wasson, 1999). We consider that we included enough information at family level to design the first version of the ABI index. This level of taxonomic resolution has demonstrated to be effective in bioassesments of water quality. In some cases family works better than genus level (Bailey et al., 2001) providing the same information at a lower effort and cost (Chessman et al., 2007). However, further studies are required to validate their tolerance to pollution, especially for other Andean areas that remain unexplored.

The autecology of the different families, their response to basin alterations and their resistance to pollution in the Andes is largely unknown. In addition, these high altitude areas have lower water oxygen contents and tolerance to pollution may differ from that reported for the same families in the lowlands or in mountains of Europe (Jacobsen, Rostgaard \& Vásconez, 2003). Although we based our report on recent autecological studies of macroinvertebrates in the area (Table 2), the scores assigned to each family should be used with caution until more information is available, especially for Coleoptera. In addition to elevation, tolerance to pollution can vary depending on the type of contamination. Studies on the effects of pollutants and ecotoxicology have focused mainly on temperate areas and pollutant behavior may differ between tropical Andean freshwaters and temperate ecosystems (Lacher \& Goldstein, 1997; Wishart, Davies, 
Boon \& Pringle, 2000). Here we addressed mainly organic pollution, but mining activities are a considerable source of pollutants to water ecosystems in south Ecuador, Peru, and Bolivia (Pringle et al., 2000). It has been estimated that approximately 5000 tons of mercury have been deposited in forest and urban environments in Latin America since the onset of the new gold expansion (Veiga, 1997 in UNEP 2000) and there is a lack of information on the effect of this kind of pollution on freshwater communities. At present, we do not know whether the current ABI values are representative of different kinds of disturbances and for this reason their application in some cases may produce misleading information on water quality. In Mediterranean regions, studies have reported that macroinvertebrates show distinct levels of resistance to different pollutants and that the final richness of a community does not necessarily reflect the ecological status of the river (Marqués, Martínez-Conde \& Rovira, 2003). In contrast, other studies report that the IBMWP scores are a useful tool to monitor waters receiving coal mine drainage (García-Criado, Tomé, Vega \& Antolín, 1999) and that this index varies not only with organic pollution but also with habitat heterogeneity and mine pollution (Solà, 2004). In this regard, ABI scores showed certain sensitivity to mining pollution in Andean streams (Ordóñez-Arízaga, 2011b; Villamarín, 2012), but additional detailed studies are still needed.

Freshwater Andean ecosystems are also greatly affected by suspended solids and the excessive use of agrochemicals. Macroinvertebrate assemblages are good indicators of suspended solid impacts in the Bolivian Andes due to road construction (Fossati, Wasson, Héry, Salinas \& Marín, 2001). Contrastingly, the effects of agrochemicals, particularly pesticides, on freshwater communities in these areas have not been widely studied (Pringle et al., 2000). Given that agrochemicals are a common source of pollution, the effects of these compounds on freshwater communities (UNEP, 2000) should be taken into account in the adaptation of a biotic index. Although the $\mathrm{ABI}$ shows some sensitivity to agricultural alterations (Ordóñez-Arízaga, 2011a; BragadoQuero, 2011), we recommend that in these cases the index should be used very carefully because the effects have not been deeply investigated (especially for pesticides).

We found the ABI to be a good representation of the environmental status of rivers, especially when studies include reference and impacted sites, and boundaries among classes are accurately assigned (e.g., Table 3). Although our sites presented physicochemical degradation, physical habitat impacts were not evident. Therefore, it is not surprising to find strong relationships between the ABI and conductivity, nitrates, reference condition and QBR-, but to with the IHF. Removing the Peruvian reference sites results in a strong correlation between ABI and IHF, thus an effective implementation of the $\mathrm{ABI}$ index requires the applications of the reference condition approach. In each basin, reference values may be different indicating that thresholds among quality classes might be different (as shown for Ecuador and Peru, Table 3). The absolute value of the index is not representative of water quality; it should be compared against reference conditions values. With this approach, the application of the ABI at two Andean subbasins in Ecuador showed a strong correlation with changes in land use (Ordoñez, 2011a). Also, a recent detailed study of the relationship of environmental factors and macroinvertebrates in high altitude Andean streams, showed also that the $\mathrm{ABI}$ is an strong indicator of the ecological quality of streams (with significant diminishing when impairment increases), and an important part of a new multimetric index for Andean streams (IMEERA Index by Villamarín, Rieradevall, Paul, Barbour \& Prat, 2013). However the relationship at basin level of multiple stressors and the aquatic biota should be better investigated in the Andes.

The geographical distribution of water pollution in the Andes is now dominated by flows from large metropolitan areas (UNEP, 2000). Large cities such as Bogotá, Medellín, Quito, Cuenca, La Paz, Cochabamba, Mérida, 
Arequipa and Cuzco are located in the Andes and population pressure, and its consequent water requirements, is increasing in these regions. Only $5 \%$ of the sewage water of the region is treated and the pollution of superficial and underground waters is becoming a controversial issue (UNEP, 2002), mainly because there is a lack of an administrative model that assure equity and environmental sustainability of the water supply (Pirez, 2000). The pressure on aquatic ecosystems is further exacerbated by the fact that Andean glaciers are threatened by climate change (Bradley, Vuille, Díaz \& Vergara, 2006). Overall, aquatic resources will decrease in the future as demand for water increases. Tools like the ABI index, the CERA protocol (Acosta et al., 2009), and multimetric indices (e.g. the IMEERA, Villamarin et al., 2013) are of increasing importance as they provide reliable and rapid results for water management institutions, from an ecosystem point of view. Moreover, the ABI index is currently the most used, with success, in the Paute basin in Ecuador (Ordoñez, 2011b).

Our study provides a basis for future studies and for the implementation of methods of ecological assessment of river water quality, as those currently used in Europe, Australia and North America. To develop these methods, exercises of method standardization for water and biota sampling, collecting, sorting and analyzing are necessary. These methods should be applied in a wide range of polluted and unpolluted sites around the Andes. Another future task in monitoring in the region is the definition of reference conditions for different types of rivers following, for example, the Water Framework Directive guidelines. Although some preliminary research has been done (Ríos-Touma, 2004; Acosta, 2005; Acosta et al., 2009; Ordóñez-Arízaga, 2011b; Villamarín 2012), there is a need to standardize sampling and data interpretation to obtain a large set of data from different river types. A further step in this research is the construction of a multimetric index (e.g., IMEERA, Villamarin et al., 2013) that uses the reference condition approach and provides another tool for biomonitoring. The $\mathrm{ABI}$ index is one of the most important components of this multimetric index, therefore, the explanations of family scores provided here are also important for the users of the IMEERA multimetric index.

The participation of management institutions, universities, local and international specialists, and civil society is important for the success of monitoring activities using a biological index like the ABI, and its usefulness in management and conservation policies. We encourage ABI users to provide feedback, comments, suggestions and results to the authors, in order to increase the knowledge and adjust the index accordingly.

\section{ACKNOWLEDGMENTS}

We thank the Freshwater Ecology and Management group at the University Barcelona, and Nuria Bonada and Alonso Ramírez who kindly commented on this article. This manuscript is the result of several research projects including CERA 1, CERA 2 and FUCARA funded by the Spanish Ministry of Education and Research and the AECID (Spanish Agency for International Cooperation and Development), for further details of the projects and complementary information, please visit www.ub.edu/riosandes. Pau Fortuño (UB) provided help with maps. Blanca Rios Touma had a doctoral fellowship from the Education for Nature Program (WWF) and Raúl Acosta a MAE scholarship. We would like to thank the collaboration of: Laboratorio de Ecología Acuática and especially to Andrea Encalada, Universidad San Francisco de Quito, and Clorinda Vergara, Museum of Entomology in La Molina University, Lima, Peru. Zan Rubin (U. C. Berkeley) kindly edited this manuscript. This support is gratefully acknowledged.

\section{RESUMEN}

Los índices bióticos basados en puntuación son ampliamente utilizados para evaluar la calidad del agua de los arroyos y ríos. Varias áreas de los Andes están densamente pobladas y hay necesidad de métodos para 
evaluar el impacto de la creciente presión humana sobre los ecosistemas acuáticos. Dadas las características ecológicas y geográficas únicas de los Andes, los índices de macroinvertebrados utilizados en otras regiones deben adaptarse con cautela. Aquí se presenta una revisión de la literatura sobre distribución de macroinvertebrados y la tolerancia a la contaminación en las zonas andinas por encima de $2000 \mathrm{msnm}$. Usando estos datos, se propone un Índice Biolótico Andino (ABI), que se basa en el índice de BMWP. En general, ABI incluye un menor número de familias de macroinvertebrados que en otras regiones del mundo donde se ha aplicado el índice BMWP porque la altitud restringe la distribución de varias de ellas. Nuestra revisión muestra que la tolerancia de varias familias a la contaminación en los ríos altoandinos difiere de lo reportado en otras áreas. Probamos el índice ABI en dos cuencas en Ecuador y Perú, y comparamos con otras adaptaciones BMWP utilizando el enfoque de condición de referencia. Nuestros resultados muestran que el índice de ABI es extremadamente útil para detectar el deterioro general de los ríos, pero que los límites entre las clases de calidad deben ser definidos independientemente para cada cuenca debido a que las condiciones de referencia pueden ser diferentes. El ABI es ampliamente utilizado en Ecuador y Perú, y es parte integral del nuevo índice multimétrico diseñado para corrientes altas andinas (IMEERA).

Palabras clave: Andes, macroinvertebrados acuáticos, distribución altitudinal, tolerancia a la contaminación, adaptaciones del BMWP, biomonitoreo, calidad del agua.

\section{REFERENCES}

Acosta, R. (2001). Patrones de distribución espaciotemporal de insectos acuáticos y caracterización limnológica de la quebrada Cantón, tributaria del río Rímac (Huarochiri, Lima). (Tesis de Licenciatura). Universidad Nacional Agraria La Molina, Lima, Perú.

Acosta, R. (2003). Evaluación de insectos acuáticos. In World Wildlife Foundation (WWF) \& Instituto Nacional de Recursos Naturales del Perú (INRENA). Evaluación biológica rápida del santuario nacional Tabaconas-Namballe y zonas aledañas. Retrieved from http://www.paramo.org/files/recursos/Informe Final_SNTN.pdf

Acosta, R. (2005). Caracterización de la comunidad de macroinvertebrados bentónicos de la Cuenca Altoandina del río Cañete (Lima, Perú). (Trabajo de investigación del programa de doctorado y diplomado en estudios avanzados en ecología). Universidad de Barcelona, España.

Acosta, R., Ríos-Touma, B., Rieradevall, M., \& Prat, N. (2009). Propuesta de un protocolo de evaluación de la calidad ecológica de ríos Andinos (C.E.R.A) y su aplicación en dos cuencas en Ecuador y Perú. Limnetica, 28(1), 35-64.

Acosta, R., \& Prat, N. (2011). Trophic ecology of Hyalella sp. (Crustacea: Amphipoda) in a high Andes headwater river with travertine deposits. International Review of Hydrobiology, 96(3), 274-285.

Alba-Tercedor, J., \& Sánchez-Ortega, A. (1988). Un método rápido y simple para evaluar la calidad biológica de las aguas corrientes basado en el de Helawell (1978). Limnetica, 4, 51-56.

Alba-Tercedor, J., Jáimez-Cuéllar, P., Álvarez, M., Avilés, J., Bonada, N., Casas, J., Mellado, A., Ortega, M., Pardo, I., \& Prat, N. (2002). Caracterización del estado ecológico de ríos mediterráneos ibéricos mediante el índice IBMWP (antes BMWP'). Limnetica, 21, 175-185.

Allmendinger, R. W., Jordan, T. E., Kay, S. M., \& Isacks, B. L. (1997). The Evolution of the Altiplano-Puna Plateau of the Central Andes. Annual Review of Earth Planetary Sciences, 25, 139-174.

Alvarenga, L., \& Ricci, C. N. (1981). Bivalvia. In S. H. Hurlbert, G. Rodríguez \& N. D. Dos Santos (Eds.), Aquatic biota of tropical south America. Part 2: Arthropoda (pp. 208-217). California: San Diego State University.

Alvarez, L. F., \& Roldán, G. (1983). Estudio del orden Hemiptera (Heteroptera) en el departamento de Antioquia en diferentes pisos altitudinales. Actualidades Biológicas, 12(14), 31-46.

Angrisano, E., \& Korob, P. G. (2001). Trichoptera. In H. R. Fernández \& E. Domínguez (Eds.), Guía para la Determinación de los Artrópodos Bentónicos Sudamericanos (pp. 55-92). Tucumán: Serie Investigaciones de la UNT, Subserie Ciencias Exactas y Naturales.

Angrisano, E., \& Sganga, J. V. (2009). Trichoptera. In E. Domínguez \& H. R. Fernández (Eds.), Macroinvertebrados bentónicos sudamericanos: sistemática $y$ biología (pp. 255-307). Tucumán: Fundación Miguel Lillo.

Arango, M. C., \& Roldán, G. (1983). Odonatos inmaduros del Departamento de Antioquia en diferentes pesos altitudinales. Actualidades Biologicas, 12(46), 91-105.

Armitage, P., Moss, D., Wright, J., \& Furse, M. (1983). The performance of a new biological water quality score system based on macroinvertebrates over a wide range of unpolluted running-water sites. Water Research, 17(3), 333-347.

Archangelsky, M., Manzo, V., Michat, M. C., \& Torres, P. L. M. (2009). Coleoptera. In E. Domínguez \& H. R. Fernández (Eds.), Macroinvertebrados bentónicos sudamericanos: sistemática y biología (pp. 411-468). Tucumán: Fundación Miguel Lillo. 
Ballesteros, Y. V., Zúñiga de Cardoso, M. C., \& Rojas de Hernández, A. M. (1997). Distribution and Structure of the order Trichoptera in various drainages of the Cauca River basin, Colombia, and their relationship to water quality. Proceedings $8^{\circ}$ International Symposium on Trichoptera 2 19-23.

Barbour, M. T., Gerritsen, J., Griffith, G. E., Frydenborg, R., McCarron, E., White, J. S., \& Bastian, M. L. (1996). A framework for biological criteria for Florida streams using benthic macroinvertebrates. Journal of the North American Benthological Society, 15, 185-211.

Barbour, M. T., Gerritsen, J., Snyder, B. D., \& Stribling, J. B. (1999). Rapid bioassessment protocols for use in streams and wadeable rivers. Washington: USEPA.

Barrios, M., \& Wolff, M. (2011). Initial study of arthropods succession and pig carrion decomposition in two freshwater ecosystems in the Colombian Andes. Forensic Science International, 212, 164-172.

Barton, D. R., \& Metcalfe-Smith, J. L. (1992). A comparison of sampling techniques and summary indices for assessment of water quality in the Yamaska River, Quebec, based on benthic macroinvertebrates. Environmental Monitoring and Assessment, 21, 225-244.

Bailey, R. C., Norris, R. H., \& Reynoldson, T. B. (2001). Taxonomic resolution of benthic macroinvertebrate communities in bioassessments. Journal of the North American Benthological Society, 20, 280-286.

Bick, G. H., \& Bick, J. C. (1985). A revision of the picta group of Polythore, with a description of a new species, P. lamerceda spec. nov., from Peru (Zygoptera: Polythoridae). Odonatologica, 14, 1-28.

Bonada, N., Prat, N., Munné, A., Rieradevall, M., AlbaTercedor, J., Álvarez, M., Avilés, J., Casas, J., Jáimez-Cuéllar, P., Mellado, A., Moyà, G., Pardo, I., Robles, S., Ramon, G., Suárez, M. L., Toro, M., Vidal-Abarca, M. R., Vivas, S., \& Zamora-Muñoz, C. (2002). Ensayo de una tipología de las cuencas mediterráneas del proyecto GUADALMED siguiendo las directrices de la directiva marco del agua. Limnetica, 21(3-4), 77-98.

Bradley, R. S., Vuille, M., Diaz, H. F., \& Vergara, W. (2006). Climate change: threats to water supplies in the Tropical Andes. Science 312, 1755-1756.

Bragado-Quero, G. (2011). Efectos del cambio del paisaje natural sobre la diversidad y funcionalidad de los ecosistemas andinos. (Tésis de Maestría). Universidad Menéndez Pelayo (España) e Universidad Tecnológica Indoamérica (Ecuador).

Carrera, P., \& Gunkel, G. (2003). Ecology of a high Andean stream, Río Itambi, Otavalo, Ecuador. Limnologica, 33, 29-43.

Chaves, M. L., Costa, J. L., Chainho, P., Costa, M. J., \& Prat, N. (2006). Selection and validation of reference sites in small river basins. Hydrobiologia, 573, 133-154.

Chessman, B. C. (1995). Rapid assessment of rivers using macroinvertebrates: A procedure based on habitatspecific sampling, family level identification and a biotic index. Australian Journal of Ecology, 20, 122-129.

Chessman, B., Williams, S., \& Besley, C. (2007). Bioassessment of streams with macroinvertebrates: effect of sampled habitat and taxonomic resolution. Journal of the North American Benthological Society, 26(3), 546-565.

Chutter, F. M. (1972). An empirical biotic index of the quality of water in South African streams and rivers. Water Research, 6(1), 19-30.

Correa, M., Machado, T., \& Roldán, G. (1981). Taxonomía y ecología del orden Trichoptera en el departamento de Antioquia en differentes pisos altitudinales. Actualidades Biológicas, 10(36), 35-48.

Corvalán, J. (1990). Geologic-Tectonic Framework of the Andean Region. In G. Ericksen, M. Cañas \& J. A. Reinemund (Eds.), Geology of the Andes and its relation to hydrocarbon and mineral resources (1-11). Huston, Texas, USA.

Cuezzo, M. G. (2009). Mollusca Gastropoda. In E. Domínguez \& H. R. Fernández (Eds.), Macroinvertebrados bentónicos sudamericanos: sistemática y biología (595-629). Tucumán: Fundación Miguel Lillo.

Czerniawska-Kusza, I. (2005). Comparing modified biological monitoring working party score system and several biological indices based on macroinvertebrates for water-quality assessment. Limnologica, 35(3), 169-176.

Domínguez, E., \& Fernández, H. R. (1998). Calidad de los ríos de la Cuenca del Sali, (Tucuman, Argentina) medido por un índice biótico. Tucumán: Serie Conservación de la Naturaleza, Fundación Miguel Lillo.

Domínguez, E., Hubbard, M. D., Pescador, M. L., Molinari, C., \& Nieto, C. (2011). Checklist of the Ephemeroptera of South America. Retrieved from www. ephemeroptera-galactica.com/

Domínguez, E., Molineri, C., \& Nieto, C. (2009). Ephemeroptera. In E. Domínguez \& H. R. Fernández (Eds.), Macroinvertebrados bentónicos sudamericanos: sistemática y biología (pp. 55-93). Tucumán: Fundación Miguel Lillo.

Dominguez, E., \& Fernández, H. R. (2009). Macroinvertebrados bentónicos sudamericanos: sistemática y biología. Tucumán: Fundación Miguel Lillo.

Fernández, H., \& Domínguez, E. (Eds.). (2001). Guía para la determinación de artrópodos bentónicos sudamericanos. Tucumán: Serie Investigaciones de la UNT, Subserie Ciencias Exactas y Naturales. 
Fernández, H. R., Romero, F., Vece, M. B., Manzo, V., Nieto, C., \& Orce, M. (2002). Evaluación de tres índices bióticos en un río subtropical de montaña (Tucumán, Argentina). Limnetica, 21(1-2), 1-14.

Figueroa, R. (2004). Calidad ambiental de la cuenca hidrográfica del río Chillán, VIII Región, Chile. (Tesis Doctoral). Universidad de Málaga, España.

Figueroa, R., Valdovinos, C., Araya, E., \& Parra, O. (2003). Macroinvertebrados bentónicos como indicadores de calidad de agua del sur de Chile. Revista Chilena de Historia Natural, 76, 275-285.

Flint, O. S. (1982). Studies of Neotropical Caddisflies, XXX: Larvae of the genera of South American Limnephilidae. Smithsonian Contributions to Zoology, 355 .

Flint, O. S. (1991). Studies of Neotropical Caddisflies, XLV: The Taxonomy, phenology, and faunistics of the Trichoptera of Antioquia, Colombia. Smithsonian Contributions to Zoology, 520.

Fossati, O., Wasson, J., Héry, C., Salinas, G., \& Marín, R. (2001). Impact of sediment releases on water chemistry and macroinvertebrate communities in clear water Andean streams (Bolivia). Archiv für Hydrobiologie, 151(1), 33-50

Froehlich, C. (2009). Plecoptera. In E. Domínguez \& H. R. Fernández (Eds.), Macroinvertebrados bentónicos sudamericanos: sistemática y biología (pp. 145-165). Tucumán: Fundación Miguel Lillo.

Gansser, A. (1973). Facts and theories on the Andes. Journal of the Geological Society of London, 29, 93-131.

García-Criado, F., Tomé, A., Vega, F. J., \& Antolín, C. (1999). Performance of some diversity and biotic indices in rivers affected by coal mining in northwestern Spain. Hydrobiologia, 394, 209-217.

Gavrilov, K. (1981). Oligochaeta. In S. H. Hurlbert, G. Rodríguez \& N. D. Dos Santos (Eds.), Aquatic biota of tropical South America. Part 2: Arthropoda (pp. 170-190). California: San Diego State University.

Gregory-Wodzicki, K. (2000). Uplift history of the central and northern Andes: A review. GSA Bulletin, 112(7), 1091-1105.

Giller, P., \& Malmqvist, B. (1998). The Biology of Streams and Rivers. UK: Oxford University Press.

Gustafson, G. T., \& Short, A. E. Z. (2010). Revision of the neotropical water scavenger beetle genus Guyanobius Spangler, 1986 (Coleoptera: Hydrophilidae: Chaetarthriini). Aquatic Insects, 32, 245-258.

Gutierrez, J. D., Riss, W., \& Ospina, R. (2004). Application of fuzzy logic as bioindication tool for the water quality with aquatic macroinvertebrates in the Sabana de Bogotá-Colombia. Caldasia, 26(1), 161-172.

Hansen, M. (1991). The hydrophiloid beetles: phylogeny, classification, and a revision of the genera
(Coleoptera: Hydrophilidae). Biologiske Skrifter, 40, 1-367.

Hanson, P., Springer, M., \& Ramírez, A. (2010). Introducción a los grupos de macroinvertebrados acuáticos. Revista de Biologia Tropical, 58(Suppl. 4), 3-37.

Hilsenhoff, W. L. (1982). Using a biotic index to evaluate water quality in streams. Department of Natural Resources Madison, Wisconsin, USA.

Hilsenhoff, W. L. (1987). An improved biotic index of organic stream pollution. Great Lakes Entomologist, 20, 31-40.

Holzenthal, R. W., \& Flint, O. S. (1995). Studies of Neotropical Caddisflies LI: Systematics of the Neotropical Caddisfly Genus Contulma (Trichoptera: Anomalopsychidae). Smithsonian Contributions to Zoology, 575 .

Holzenthal, R., \& Rios-Touma, B. (2012). Contulma paluguillensis (Trichoptera: Anomalopsychidae), a new caddisfly from the high Andes of Ecuador and its life history, habitat, and ecology. Freshwater Science, $31(2), 442-450$.

Illies, J. (1964). The invertebrate fauna of Huallaga, a Peruvian tributary of the Amazon River, from the sources down to Tingo Maria. Verh. Internat. Verein. Limnol., 15, 1077-1083.

Illies, J. (1969). Biogeography and ecology of neotropical freshwater insects, especially those from running waters. In E. J. Fittkau, J. Illies, H. Klinge, G.H. Schwabe \& H. Sioli (Eds.), Biogeography and Ecology in South America (pp. 685-707). The Hague: Dr. W. Junk N. V.

Ituarte, C. (2009). Mollusca Bivalvia. In E. Domínguez \& H. R. Fernández (Eds), Macroinvertebrados bentónicos sudamericanos: sistemática y biología (pp. 567594). Tucumán: Fundación Miguel Lillo.

Jacobsen, D., Schultz, R., \& Encalada, A. (1997). Structure and diversity of stream invertebrate assemblages: the influence of temperature with altitude and latitude. Freshwater Biology, 38, 247- 261

Jacobsen, D. (1998). The effect of organic pollution on the macroinvertebrate fauna of Ecuadorian highland streams. Archiv für Hydrobiologie, 143(2), 179-195.

Jacobsen, D., \& Encalada, A. (1998). The macroinvertebrate fauna of Ecuadorian highland streams in the wet and dry season. Archiv für Hydrobiologie, 142(1), $53-70$

Jacobsen, D. (2003). Altitudinal changes in diversity of macroivertebrate from small streams in the Ecuadorian Andes. Archiv für Hydrobiologie, 158 (2), 145-167.

Jacobsen, D., Rostgaard, S., \& Vásconez, J. J. (2003). Are macroinvertebrates in high altitude streams affected by oxygen deficiency? Freshwater Biology, 48, 2025-2032. 
Jacobsen, D. (2004). Contrasting patterns in local and zonal family richness of stream invertebrates along an Andean altitudinal gradient. Freshwater Biology, 49, 1293-1305.

Kattan, G., Franco, P., Rojas, V., \& Morales, G. (2004). Biological diversification in a complex region: a spatial analysis of faunistic diversity and biogeography of the Andes of Colombia. Journal of Biogeography, 31, 1829-1839.

Lacher, T. E., \& Goldstein, M. I. (1997). Annual Review - Tropical Ecotoxicology: Status and needs. Enviromental Toxicology and Chemistry, 26, 100-111.

Lavenu, A. (2006). Neotectónica de los Andes entre $1^{\circ} \mathrm{N}$ y $47^{\circ} \mathrm{S}$ (Ecuador, Bolivia y Chile): una revisión. Revista de la Asociación Geológica Argentina, 61(4), 504-524.

Leiva, M. J. (2004). Macroinvertebrados bentónicos como bioindicadores de calidad de agua en la cuenca del Estero Peu Peu comuna de Lautaro IX Región de la Araucania (Tesis de Licenciatura). Universidad Católica de Temuco, Chile.

Lizarralde de Grosso, M. (2001). Diptera. Generalidades. In H. R. Fernández \& E. Domínguez (Eds.), Guía para la Determinación de los Artrópodos Bentónicos Sudamericanos (pp. 155-165). Tucumán: Serie Investigaciones de la UNT, Subserie Ciencias Exactas y Naturales.

Lizarralde de Grosso, M. (2009). Diptera. In E. Domínguez \& H. R. Fernández (Eds.), Macroinvertebrados bentónicos sudamericanos: sistemática y biología (pp. 341-364). Tucumán: Fundación Miguel Lillo.

Machado, T., \& Rincón, J. (1996). Coleoptera. In G. Roldán (Ed.), Guía para el estudio de los macroinvertebrados acuáticos del departamento de Antioquia (pp. 116-144) Bogotá: Pama Editores Ltda.

Machado, T., Urán, A., Ramírez, J., Lenis, G., Wills, A., Villegas, N., Blandón, M., \& González, M. (1997). Aspecto Biológico y Fisicoquímico del río Medellín. Estado Social, Económico y Ambiental del Río Medellín. Tomo I. Medellín: Instituto Mi Río, Universidad de Antioquia.

Marchese, M. R. (2009). Annelida Oligochaeta. In E. Domínguez \& H. R. Fernández (Eds.). Macroinvertebrados bentónicos sudamericanos: sistemática y biología (pp. 551-564). Tucumán: Fundación Miguel Lillo.

Marqués, M. J., Martínez-Conde, E., \& Rovira, J. V. (2003). Effects of zinc and lead mining on the benthic macroinvertebrates of a fluvial ecosystem. Water, Air, and Soil Pollution, 148, 363-388.

Mazzuconi, S. A, López Ruf, M. L., \& Bachmann, A. O. (2009). Hemiptera-Heteroptera: Gerromorpha y Nepomorpha. In E. Domínguez \& H. R. Fernández (Eds.). Macroinvertebrados bentónicos sudamericanos: sistemática y biología (pp. 167-231). Tucumán: Fundación Miguel Lillo.

Merrit, R. M., \& Cummins, K. W. (Eds.). (1996). An Introduction to the Aquatic Insects of North America. Dubuque: Kendall/Hunt Publishing Company.

Monaghan, K. A., Peck, M. P., Brewin, P. A., Masiero, M., Zarate, E., Turcotte, P., \& Ormerod, S. J. (2000). Macroinvertebrate distribution in Ecuadorian hill streams: the effects of altitude and land use. Archiv für Hydrobiologie, 149 (3), 421-440

Munné, A., \& Prat, N. (2009). Use of macroinvertebratebased multimetric indices for water quality evaluation in Spanish Mediterranean rivers: an intercalibration approach with the IBMWP index. Hydrobiologia, 628, 203-205.

Mustow, S. E. (2002). Biological monitoring of rivers in Thailand: use and adaptation of the BMWP score. Hydrobiologia, 479(1-3), 191-229.

Myers, N., Mittermeier, R. A., Mittermeier, C. G., da Fonseca, G. A. B., \& Kent, J. (2000). Biodiversity hotspots for conservation priorities. Nature, 403, 853-858.

Oficina Nacional de Evaluación de Recursos Naturales (ONERN). (1970). Inventario, evaluación y uso racional de los recursos naturales de la costa: cuenca del río Cañete. Lima, Perú.

Ordóñez-Arízaga, V. (2011a). Influencia del uso del suelo y la cobertura vegetal natural en la integridad ecológica de los ríos altoandinos al noreste del Ecuador (Tésis de Maestría). Universidad San Francisco de Quito, Quito, Ecuador.

Ordóñez-Arízaga, V. (2011b). Análisis de la información sobre el uso de bioindicadores acuáticos en la cuenca del rio Paute, Ecuador. Fideicomiso Mercantil Fondo del Agua para la Conservación de la Cuenca del Río Paute (FONAPA). CD-FONP2-02. Cuenca, Ecuador.

Paraense, W. L. (1981). Gastropoda. In S. H. Hurlbert, G. Rodríguez \& N. D. Dos Santos (Eds.), Aquatic Biota of Tropical South America. Part 2: Arthropoda (pp. 200-207). California: San Diego State University.

Paulson, D. (2012). List of the Odonata of South America, by Country. Retrieved from http://www. pugetsound.edu/academics/academic-resources/ slater-museum/biodiversity-resources/dragonflies/ south-american-odonata/

Peralta, M. A. (2001). Crustacea Eumalacostraca. In H. R. Fernández \& E. Domínguez (Eds.), Guía para la determinación de los artrópodos bentónicos Sudamericanos (pp. 257-282). Tucumán: Serie Investigaciones de la UNT, Subserie Ciencias Exactas y Naturales.

Peralta, M., \& Grosso, L. E. (2009). Crustacea, Syncarida, Amphipoda y Decapoda. In E. Domínguez \& H. R. Fernández (Eds.), Macroinvertebrados bentónicos 
sudamericanos: sistemática y biología (pp. 469-495). Tucumán: Fundación Miguel Lillo.

Perkins, P. D. (2011). New records and description of fifty-four new species of aquatic beetles in the genus Hydraena Kugelann from South America (Coleoptera: Hydraenidae). Zootaxa, 3074, 1-198.

Pescador, M. L., Hubbard, M. D., \& Zúñiga, M. C. (2001). The status of the taxonomy of the mayfly (Ephemeroptera) fauna of Southamerica. In E. Domínguez (Ed.), Trends in research in Ephemeroptera y Plecoptera (pp. 37-42). New York: Kluwer Academics/ Plenum Publishers.

Pirez, P. (2000). Servicios urbanos y equidad en América Latina, serie medio ambiente y desarrollo. Santiago: United Nations Economic Commission for Latin America and the Caribbean.

Posada, A., Roldán, G., \& Ramírez, J. J. 2000. Caracterización fisicoquímica y biológica de la calidad de aguas de la cuenca de la quebrada Piedras Blancas, Antioquia, Colombia. Revista de Biología Tropical, 48(1), 59-70.

Prat, N., Ríos-Touma, B., Acosta, R., \& Rieradevall, M. (2009). Los macroinvertebrados como indicadores de la calidad del agua. In E. Domínguez \& H. R. Fernández (Eds.), Macroinvertebrados bentónicos sudamericanos: sistemática y biología (pp. 631-654). Tucumán: Fundación Miguel Lillo.

Pringle, C. M. (2000). River conservation in tropical versus temperate latitudes. In P. J. Boon, B. Davies \& G. E. Petts (Eds.), Global perspectives on river conservation. Science, policy and practice (pp. 371-384). New York: John Wiley and Sons Ltd.

Pringle, C. M., Scatena, F. N., Paaby-Hansen, P., \& NúñezFerrera, M. (2000). River conservation in Latin America and the Caribbean. In P. J. Boon, B. R. Davies \& G. E. Petts (Eds.), Global perspectives on river conservation: science, policy and practice (pp. 41-77). New York: John Wiley and Sons Ltd.

Resh, V. H. (1995). Freshwater benthic macroinvertebrates and rapid assessment procedures for water quality monitoring in developing and newly industrialized countries. In W. S. Davis \& T. P. Simon (Eds.), Biological assessment and criteria: Tools for water resource planning and decision making (pp. 167180). USA: CRC press, Inc.

Reynoldson, T. B., Norris, R. H., Resh, V. H., Day, K. E., \& Rosenberg, D. M. (1997). The reference condition: A comparison of multimetric and multivariate approaches to assess water-quality impairment using benthic macroinvertebrate. Journal of the North American Benthological Society, 16 (4), 833-852.

Ringuelet, R. A. (1981). Hirudiena. In S. H. Hurlbert, G. Rodríguez \& N. D. Dos Santos (Eds.), Aquatic Biota of Tropical South America. Part 2: Arthropoda (pp. 191-196). California: San Diego State University.
Ríos-Touma, B. P. (2004). Las comunidades de macroinvertebrados bentónicos de dos cuencas altoandinas del Ecuador. (Trabajo de Investigación del programa de Doctorado y Diplomado en Estudios Avanzados en Ecología). Universitat de Barcelona, Barcelona, España.

Ríos-Touma, B. P., \& Prat, N. (2004). Estudio de las condiciones de referencia de las cuencas de los rios Pita, San Pedro y Machángara. Informe 2: Estado ecológico de los ocho puntos del sistema de monitoreo ambiental de la EMAAP-Q estudiados (San Pedro, Machángara y Guayllabamba). Barcelona: Universitat de Barcelona.

Riss, W., Ospina, R., \& Gutierrez, J. D. (2002). Establecimiento de valores de bioindicación para los macroinvertebrados acuáticos de la Sabana de Bogotá. Caldasia, 24, 135-156.

Roback, S. S. (1980a). Plecoptera Nimphs. In S. S. Roback, L. Berner, O.S. Flint, N. Nieser \& P.J. Spangler (Eds.). Results of the catherwood Bolivian-Peruvian Altiplano Expedition Part I. Aquatic insect except Diptera. Proceedings of the Academy of Natural Sciences of Philadelphia, 195.

Roback, S. S. (1980b). Odonata Nymphs. In S. S. Roback, L. Berner, O. S. Flint, N. Nieser \& P. J. Spangler (Eds.). Results of the Catherwood Bolivian-Peruvian Altiplano Expedition Part I. Aquatic Insect except Diptera. Proceedings of the Academy of Natural Sciences of Philadelphia, 186.

Roback, S. S., Berner, L., Flint Jr, O. S., Nieser, N., \& Spangler, P. J. (1980). Results of the Catherwood Bolivian-Peruvian Altiplano Expedition Part I. Aquatic Insects except Diptera. Proceedings of the Academy of Natural Sciences of Philadelphia, 176-217.

Roback, S. S., \& Coffman, W. P. (1983). Results of the catherwood Bolivian-Peruvian altiplano expedition Part II. Aquatic Diptera including Montane Diamesinae and Orthocladiinae (Chironomidae) from Venezuela. Proceedings of the Academy of Natural Sciences of Philadelphia 135, 9-79.

Rocabado, G., \& Wasson, J. G. (1999). Regionalización de la fauna bentónica en la cuenca Andina del río Beni (Bolivia). Revista Boliviana de Ecología y Conservación Ambiental, 6, 121-132.

Roldán, G., Builes, J., Trujillo, C. M., \& Suárez, A. (1973). Efectos de la contaminación industrial y doméstica sobre la fauna béntica del río Medellín. Actualidades Biológicas, 2(4), 54-64.

Roldán, G. (1980). Estudios limnológicos de cuatro ecosistemas neotropicales diferentes con especial referencia a su fauna de efemerópteros (Clase: Insecta, Orden: Ephemeroptera) en el Departamento de Antioquia, Colombia. Actualidades Biológicas, 14(51), 3-13. 
Roldán, G. (1996). Guía para el estudio de los macroinvertebrados acuáticos del departamento de Antioquia. Bogotá: Pama Editores Ltda.

Roldán, G. (1999). Los macroinvertebrados y su valor como indicadores de la calidad del agua. Revista de la Academia Colombiana de Ciencias Exactas, Físicas y Naturales, 23(88), 375-387.

Romero, F. (2001). Plecoptera. In H. R. Fernández \& E. Domínguez (Eds.), Guía para la determinación de los artrópodos bentónicos sudamericanos (pp. 93-110). Tucumán: Serie Investigaciones de la UNT, Subserie Ciencias Exactas y Naturales.

Romero, F., \& Navarro, F. (2009). Lepidóptera. In E. Domínguez \& H. R. Fernández (Eds.), Macroinvertebrados bentónicos sudamericanos: sistemática y biología (pp. 309-340). Tucumán: Fundación Miguel Lillo.

Rosso de Ferradás, B., \& Fernández, H. R. (2001). Acari. In H. R. Fernández \& E. Domínguez (Eds.), Guía para la determinación de los artrópodos bentónicos sudamericanos (pp. 237-256). Tucumán: Serie Investigaciones de la UNT, Subserie Ciencias Exactas y Naturales.

Rosso de Ferradás, B., \& Fernández, H. R. (2009). Acari, Parasitengona, Hydrachnidia. In E. Domínguez \& H. R. Fernández (Eds.), Macroinvertebrados bentónicos sudamericanos: sistemática y biología (pp. 497-549). Tucumán: Fundación Miguel Lillo.

Sánchez-Herrera, M., \& Realpe, E. (2010). Population structure of Polythore procera at a Colombian stream (Odonata: Polythoridae). International Journal of Odonatology, 13(1), 27-37.

Solà, C. (2004). Impacte de l'accident miner d'Aznalcóllar sobre el riu Guadiamar. Recuperació de la comunitat de macroinvertebrats $i$ bioacumulació de metalls pesants. (PhD Thesis). Universitat de Barcelona, Barcelona, España.

Spangler, P. (1980). Aquatic Coleptera. In S. S. Roback, L. Berner, O. S. Flint, N. Nieser \& P. J. Spangler (Eds.) Results of the Catherwood Bolivian-Peruvian Altiplano Expedition Part I. Aquatic Insect except Diptera. Proceedings of the Academy of Natural Sciences of Philadelphia, 132, 199-212

Skoulikidis, N. T. H., Gritzalis, K., \& Kouvarda, T. H. (2002). Hydrochemical and ecological quality assessment of a mediterranean river system. Global nest: The International Journal, 4(1), 29-40.

Tachet, H. (2000). Invertébrés d'eau douce: systématique, biologie, écologie. Paris: CNRS éditions.

Tomanova, S., \& Tedesco, P. A. (2007). Body size, ecological tolerance and potential for water quality bioindication in the genus Anacroneuria (Plecoptera: Perlidae) from South America. Revista de Biologia Tropical, 55, 67-81.
Turcotte, P., \& Harper, P. (1982). The macroinvertebrate fauna of an Andean stream. Freshwater Biology, 12, 411-419.

Ulloa, C., \& Jørgensen, P. M. (2004). Árboles y arbustos de los Andes del Ecuador. Retrieved from http://www. efloras.org/flora_page.aspx?flora_id=201

United Nations Environmental Programme (UNEP). (2000). Latin America and the Caribbean. Mexico: Global Environment Outlook (GEO).

United Nations Environmental Programme (UNEP). (2002). Latin America and the Caribbean. Nairobi, Kenya: Global Environment Outlook 3 (GEO).

Valencia, R., Cerón, C., Palacios, W., \& Sierra, R. (1999). Las formaciones naturales de la sierra del Ecuador. In R. Sierra (Ed.), Propuesta preliminar de un sistema de clasificación de vegetación para el Ecuador continental (pp. 79-108). Quito: Proyecto INEFAN/ GEF-BIRF y EcoCiencia.

Vásconez, J. (2000). Resistencia de macroinvertebrados bentónicos a la contaminación orgánica en ríos de altura y de tierras bajas en Ecuador. (Tesis de Licenciatura). Pontificia Universidad Católica del Ecuador, Ecuador.

Veiga, M. M. (1997). Introducing new technologies for abatement of global mercury pollution in Latin America. Rio de Janeiro: UNIDO/UBC/CETEM/CNPq.

Villamarín, C. (2012). Estructura y composición de las comunidades de macroinvertebrados acuáticos en ríos altoandinos del Ecuador y Perú. Diseño de un sistema de medida de la calidad del agua con índices multimétricos. (Tesis Doctoral). Universitat de Barcelona, Barcelona, España.

Villamarín, C., Rieradevall, M., Paul, M. J., Barbour, M. T., \& Prat, N. (2013). A tool to assess the ecological condition of tropical high Andean streams in Ecuador and Peru: The IMEERA index. Ecological Indicators, 29, 79-92.

Viña-Vizcaíno, G., \& Ramírez-González, A. (1997). Criterios de calidad del agua y su relación con el bentos en el área de influencia del oleodúcto Cusiana-Coveñas. Seminario Internacional sobre Macroinvertebrados Bentónicos como Bioindicadores de Calidad de Agua, Santiago de Cali, Colombia.

Von Ellenrieder, N., \& Garrison, R. W. (2009). Odonata. In E. Domínguez \& H. R. Fernández (Eds.). Macroinvertebrados bentónicos sudamericanos: sistemática y biología (pp. 95-143). Tucumán: Fundación Miguel Lillo.

Water Framework Directive (WFD). (2000). Directive 2000/60/EC of the European Parliament and of the Council of 23 October 2000 establishing a framework for Community action in the field of water policy. OJ L 327, 22.12.2000. 
Wishart, M. J., Davies, B. R., Boon, P. J., \& Pringle, C. M. (2000). Global disparities in river conservation: "First World" values and "Third World" realities. In P. J. Boon, B. R. Davies \& G. E. Petts (Eds). Global Perspectives on River Conservation (pp. 353-369). Science, Policy and Practice. New York: John Wiley and Sons Ltd.

Woodiwiss, F. (1964). The biological system of stream classification used by the Trent River Board. Chemistry and Industry 14, 443-447.
Zamora-Muñoz, J. J., \& Alba-Tercedor, J. (1996). Bioassessment of organically polluted Spanish rivers, using a biotic index and multivariate methods. Journal of the North American Benthological Society, 15(3), 332-352.

Zúñiga de Cardozo, M. C., Rojas de Hernández, A. M., \& Mosquera, S. (1997). Biological aspects of Ephemeroptera in rivers of southwestern Colombia (South America). In P. Landolt \& M. Sartori (Eds.), Ephemeroptera and Plecoptera: Biology-Ecology-Systematics (pp. 261-268). Switzerland: Mauron-Tinguely and Lachat S.A. Fribourg. 


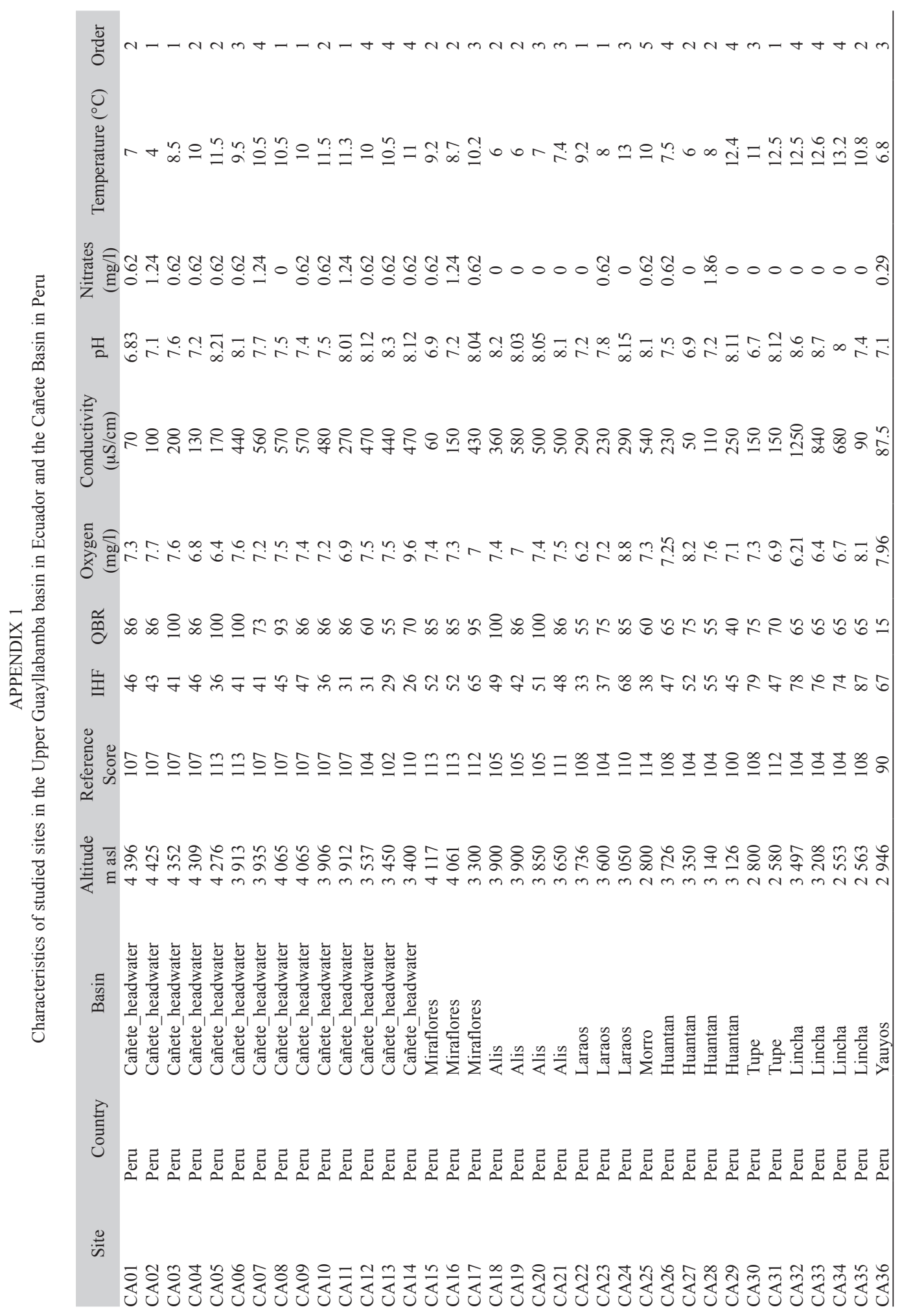




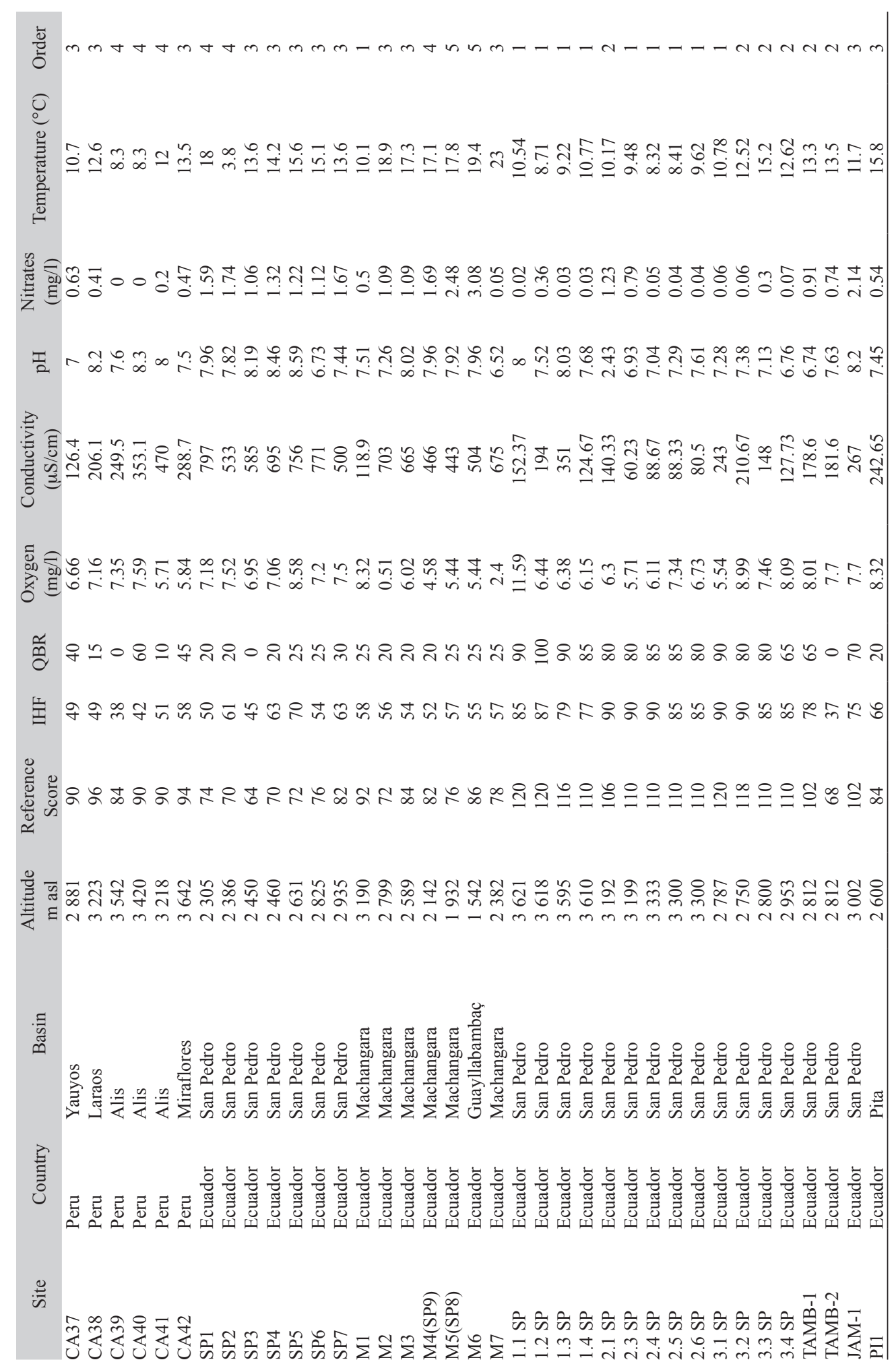




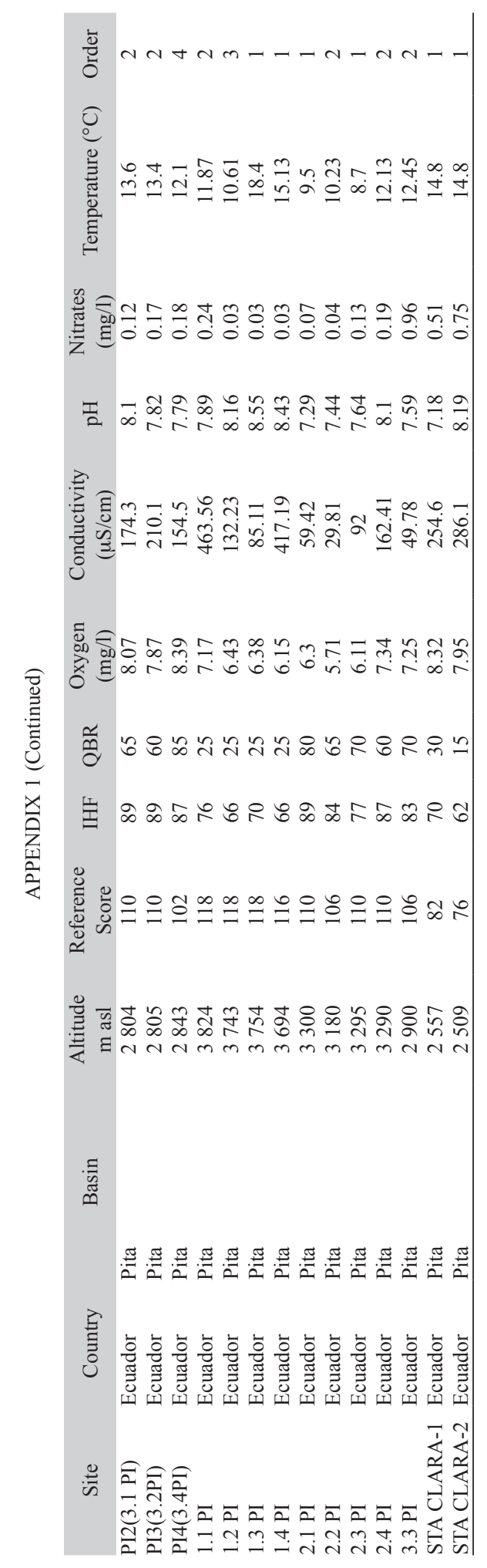


